\title{
Mitotic Activity in the Human Epidermis
}

\author{
Lawrence Einar Scheving \\ Loyola University Chicago
}

Follow this and additional works at: https://ecommons.luc.edu/luc_diss

Part of the Medicine and Health Sciences Commons

\section{Recommended Citation}

Scheving, Lawrence Einar, "Mitotic Activity in the Human Epidermis " (1957). Dissertations. 473.

https://ecommons.luc.edu/luc_diss/473

This Dissertation is brought to you for free and open access by the Theses and Dissertations at Loyola eCommons. It has been accepted for inclusion in Dissertations by an authorized administrator of Loyola eCommons. For more information, please contact ecommons@luc.edu. (c) $(i) \Theta(\Theta$

This work is licensed under a Creative Commons Attribution-Noncommercial-No Derivative Works 3.0 License. Copyright $\odot 1957$ Lawrence Einar Scheving 


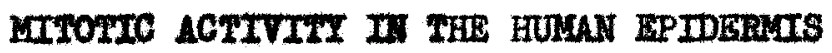

by

LAWREFCE EIUR SCHEVINO

A Dissertation Subnitted to the Faculty of the Araduate School of Loyole University in Partial Furiliment of the Requirements for the Degree of Doctor of Philosophy

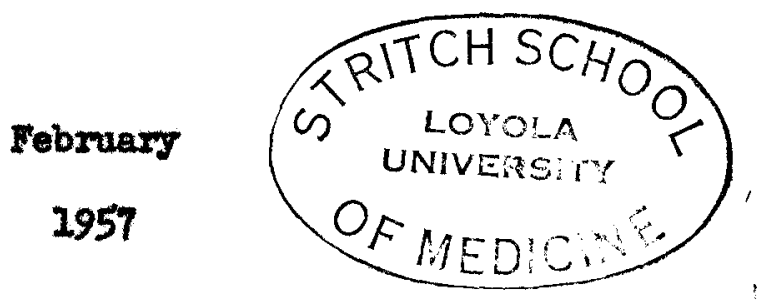




\section{TIIE}

Lawrance E. Bcheving was born in Hensel, North Dakota, October 20, 1920.

He was graduated from Eensel Public Hgh School, Hensel, North Dakota in June 1938. Trom 1938 to 1940 he attended Askers Busineas College, Grand Forks, North Dakota. From 1940 to 1946 he was a member of the United States Armed Forces. In 1946 he began undergraduate work at De Pmul Univerm gity and recelved the Bechelor of Sclence Degree fran there in February 1949. He also recelved the Haster of Selence degree from De Paul University in June 1950. He began graduate studies in the Department of Anatoun of Loyola University in June 2951.

From 1950 to the present he has taught in the Department of B1010gical Science at Lewls College of Solence and Technolog;, Lockport, Illinois. 


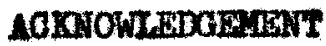

To Dr. Arthur J. Gats, under whose suggestion this problem was undertaken, I wish to express my indebtedness and to sincerely thank him for his constructive supervision and untiring assistance.

I am deeply grateful to the donors and to Dr. Donal O'Sullivan who performed all of the biopsies.

iv 


\section{TABIE OF COMHETIS}

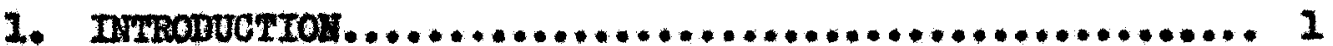

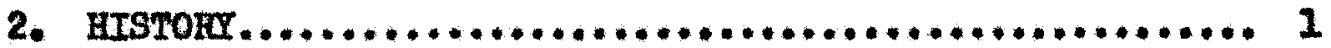

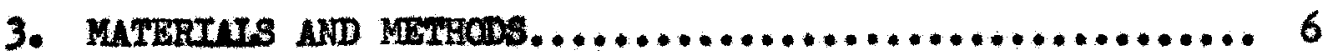

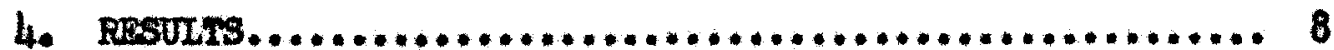

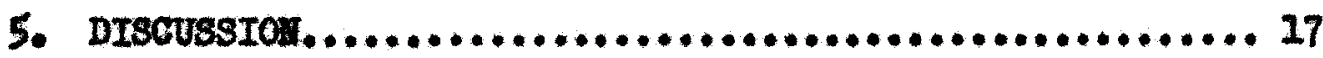

6. $\operatorname{sgnhH} \ldots \ldots \ldots \ldots \ldots \ldots \ldots \ldots \ldots \ldots \ldots \ldots \ldots \ldots \ldots \ldots \ldots \ldots \ldots \ldots \ldots \ldots \ldots 22$

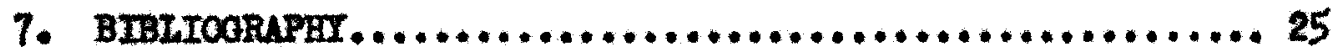

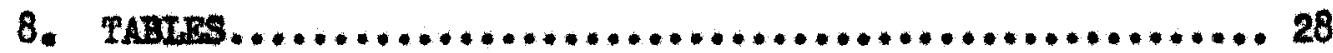

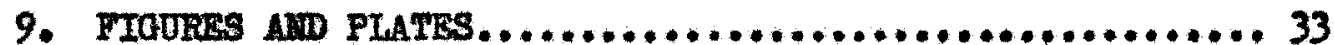

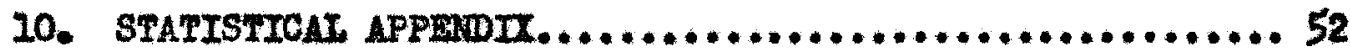




\section{MITOTIC ACTIITT IN THE HUSAN EPTDERMS}

Three riewpoints eurrently exist regarding the replacement mechanism of desquamated skin. They are; (a) mitotic division of pro-axisting cells, (b) amitotio division of epiderral cells and (o) migration and morphologioal transformation of lymphocytes and/or other types of mesodermal cells into epitheliel cells.

This research was undertaken to investigate this problem in greater detail than has been done up to the present time with the view of establiahing which method, if any, offers the most feasiblo explanation. The amall number of mitotic ffgures which have been observed on the usual histological preparation has led many workers to assume that mitotic replacement could not mainmtain the epidermal layer. Mitotic rhythmict has been observed in plants and animals. We felt that this retght also ocour in the human epidernis.

We also observed the numbers of lymphocytes in the epidermis since they, or other types of mesodermel cells, have been suggested to replace the desquamating epidermal cells.

\section{HISTORI}

Te give some idea of how many mitotie figures have been counted in adequately preserved material wo can cito the work of Thuringer (1924 and 1928) who counted one mitosis for 2,414 cells on the scalp, for 268,275 cells 
on the ear, and for 378,325 cells on the leg. P1nkus in 1953 while reviewing work done on this subject prepared a table in the form of mitotio indices (mitoses counted per thousand cells). In this surmary, wich is a report on the results of elght workerg, it is noted that the mitotic index of various regions of the human epidernils is conalderably higher than that reported by Thuringer. In the table most of the indices for the adult human epidernils range frow 1.6 to 0.1 .

The rate of cellular desquamation for the normal human sicin has been studied by only one worker. Sutton (1938) applied silver nitrate to the surface of varlows parts of his boty. He found that a period of seren to eleven days elapsed before the stained area was worn off. He concluded that this was the time needod for renewal of the stratum cornoum, which he estimated to consiat of eight cell layers.

A number of Investigators have postulated that the epldermal cells have mesodermal orlgin, or a source other than epithellal. Frieboes (1920) considered the epidermis as arneytiun without cell boundartes which is permeated by tonoflbrilue gystems originating in specialized mothermells of mesodermal character. In 1928, Bostrocm matntained that the epidermis was continualiy renewed by conversion of connective-tissue cells into epitheliel celle. As recentiy as 1950 a somewhat similar fiew was proposed by Levander. Cameron (1936) stated that "opindle-sheped" nesodermal ceIls, migrated into the epidermis of both normal and X-rayed skin. These subsequently differentiated into epithelial cells. Subjecting the amimals to $X$-rays decreased the already low numbers of mitotic figures without changing 
the epidermal thicioness. However, an increase in the mesodermal cells benenth the epldermis was observed whtch Cameron postulated would eventually migrate into the eplderists.

Andrew and Andrew in 1949 introduced the hypothesis that transformation of lymphocytes into epithelial cells occurred in the human epidemis. The migrating lymphoeytes beeame transformed into "clear cells", which later differentiated into the epidemal cells. All of the above vienpotnts were perhape prompted by the supposediy insufficient rate of epldernal mitosis.

The second possibility to acoount for the pawalty of mitotse figares would be explained by the fact that mitotio activity occurs in "bursts" or that there is a periodic rytho.

Rhythule mitotie cyoles were first imrestigated in plants. Ke121cott, in 1904, found mitotic activity to be at its mosmon helght at 21,00 P.M. in the omion root tip, and that the lesst amount of activity was seen at 7:00 1.M. Karsten (1918) reported that the greatest amount of ultotic activity in Spirogra was at 12,00 midnight. For zea mais mitotie actirity reached a maximum during the night with the least amount of activity during the day. In 1921 staifolt reported maximu activity for collular division in the Plsum

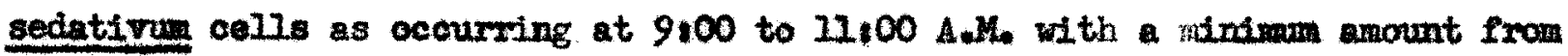
9:00 to 11:00 P.M. It 16 generally recognized, from the above work and also from numerous other investigations, that a periodic mitotic rhythm does exist in the cell diviaion of the organs of many plants. 
Portuyavan Leyden (1916 and 1926) was the flret Investigator to report this phencmenon in animel tissues. Using six young leitiens, sacrifleed at different hours during the day, she concluded that the greatest anount of mftotie activity in the mesenteries, thyme, spleen, and lymph node was essentitaly at 2,30 A.M. and the least amount at 2:30 P.M. However, the maxdman muber of mitoses occurred between 6,30 and 12:30 P.M. in the crypts of Lieberkihn of the man intestine. The mintman numer occurred at 10,30 A.K. On the contrary when usting mice instead of cats, she found the maximan mitotic activity in the intestinal glands to occur at $11,00 \mathrm{A.H}$. The miniman activity was at 3100 A.M. It Is evident that the maxima and minim raried for the two antmals, and to a lesser extent for the different tissues of the same animar.

A muber of investigaters have studied the mitotic activity of the mouse opiderms. Ortiz-P1con, in 1934, found the holght of mitotic ectivity to be at 12:00 noon with lowest activity at 12:00 P.M. In 1940, Cooper and Franklin were generally in agreament as was Bullough, in 1948, when they reported highest activity between 10,00 A.K. and 4,00 P.K. with a peak at approcimately 1,00 P.M. Carieton, in 1934, was not in agreement with the above as she contended the highest activity oceurred between 8.00 P.M. and 12:00 A.H., being lowest at 12,00 noon. The abore results would indicete that considerable variation has been observed on the same tiasue by different workers.

Another group working on the opidermis of the rat, notably, Blumenfeld (1939). Babick (1951) and Halberg and comorkers (1954), observed that 
the peak of cellular diviaton occurred at epproxinately 9,00 A.K. with lowest activity at night.

Cooper and Schiff, 1938, reported mitotio activity to be highest at 9:00 P.M. and lowest at 10,00 A.M. in the epidermal portion of the humen infant prepuce. Broders and Dublin in 1939 concluded that cellular diviofion in foreskins of now-born human beings was approximately tulce as frequont at night as in the daytime. Thirteen and twelve specinens respectively were used for these observations!

A further point of interest was indicated by the fact that the mitotic rhyth raried from organ to organ within the same animal or plant. For example Blumenfeld, (19/4), subsequent to his investigation of the epldemils, made a comparative study of the rate of mitotic activity in two additional organs, the renal cortex and the submaxiliery gland. In the renal cortex the maxdmou frequency was during the afternoon and in the submaxillary gland activity was fairiy constant during the day and night with the exception of a sharp decline between 2,00 and 4,00 A.M. This of course would indicate different rythe in different organs. On the contrary, Bullough (1948) in his comparative study of different organs apecifically the esophagus, opldidymis and duodenal moose found that they generally agreed with his findings for mitotic activity in the aldn. Milletti (1950), however, reported a definite diumal raythn in the maltiplication of cells in the bone marrow from the femur of the mouse. The peak of this activity was at 4t00 A.M. with the mintmal diviaions occurring at mid-day. 
Ellott in 1936 found no evidence of mitotic rythmicity in immature or mature cartilege of cats, dogs, rabbits, mice or rats. This may have been due to the lack of material.

\section{MATERTALS ARD METHODS}

Samples of apparently healthy skin were collected in two ways, first, by surgical procedure from patients undergoing surgery for one reason or another and secondly by biopsy from rolunteers. Five hundred samples of skin were collected by the first method and one hundred and eighty by the second. OrIginally it was planned to utillze the tissue collected by the two methods but later this was abendoned beeanse the semples collected by surglcal procedure from persons undergoing surgery were concentrated during the morning hours when most surgery is naturally performod. Too few specimens from night hours were available. The Hssue from volunteers was more equaliy distributed over day and night periods. Furthermore, the tiasue collected by the biopsy procedure gave us tIssue from healthy, young men of an average age of approximately twenty. In twelve instances the rame rolunteer subjected himself for biopsy at two or three additional times during the twenty-four hour period.

The volumteer for sidn blopstes were scheduled to appear in groups of ten at all hours during the day and evening, except for the hours of 6,00 and 7,00 A.H. The skdn was removed from ther the right or left shoulder of the rolunteer by Dr. O'Sullivan, using a 4 man sidn blopsy punch. (Latter was supplied through the courtesy of Dr. Cleveland J. White.) The tissue sample 
was placed in Bouin's fixative for at least twentymfour houre. Dehydration was accomplished by the usual alcohal procedure, it was then aleared in xylol and smbedied in paraffin.

Tro milifineter strips of the entire depth of the epidemis were carefully measured on the olldes made from each sample. All the cells in approximately four milimeters of tiasue fron ach sample were counted in this fashion. All the cells counted, which usually totaled 2,500 to 3,000 for the four millimeter strip, were classifled into lymphocytes, clear cells, chromosomal, reconstruction and "resting" or metabolle cells. The measurements of each of these two millimeter strips were made near the margin of the section in order to avoid plaiding areas indiscriminately from the section. Bach of the two counted areas mentioned above as a consequanoe were widely separated. An average of 9,2 biopsies per hour from 8,00 A.the through 5,00 A.M. were studied in this project.

Experimentel results woro subjected to statistical analyols by known raliable methods.

The arithmetical moan by the formule $I=\frac{\text { id }}{n}$ where a the variate or individual sample where $\mathrm{I}$ - the mean of the variable or total of the indirldual semples for the perlod divided by $n$

where $\mathrm{n}$ - the number of rarlates within the varlable

The standard deviation by the formulas $s-\sqrt{\frac{(d-\pi)^{2}}{a(n-I)}}$ 
The signifleance of differences were determined according to the mothod of Floher by the following expanded formulat

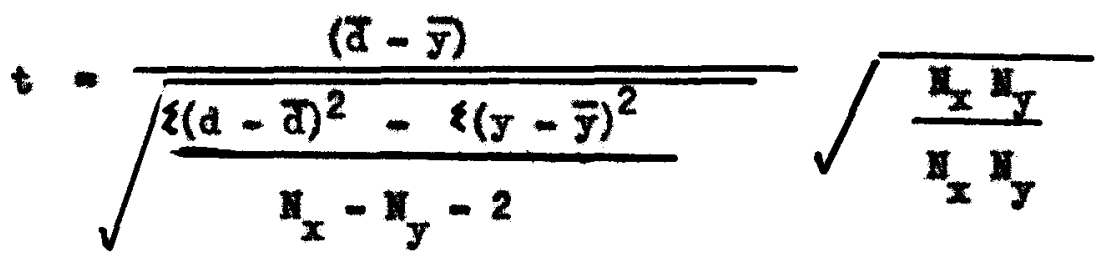

there $I$ - the axthmettical mean of the experimental rariable

where $\overline{\bar{y}}$ - the arlthmetical mean of the control variable where $(d-d)=$ the wan of the extent to which the verlates differ from their mean velue in relation to the experimental

where $(y-\bar{y})$ - the same as $(d-D)$ except that it pertuins to the control

where $I_{I}$ - the number in the control variable where $I_{f}$ - the number in the expeximentel rariable

The probability or $P$ values were taken from a standard table based on the value of $t$ and the number of varlates.

\section{EXPERTIEMAL RESULTS}

General observation of the opidermel seetions showed a considerable variation in the morpholog of the opideral cells. The majortty of the oclls, pecullar to each layer, were readily identified as the metabolle or "resting ceII" stage. 
The epldermis was composed of two layere: the stratum germinativum (stratum mocosum) above the dermis and resting on a basement membrane, of ten celled the Ifving components and the superficlal layer, the comteled stratum corneum, commonly referred to as consisting of non-living cells (Figure 8).

The stratum germinativan (or mucosum) ordinarily consisted of three zones. The stratum batale consisted of single proximal layer of cells which had basel processes enbedded in the oubstance of the besenent membrane. The Latter membrane demarested the demis and epldemis (Figure 9). The stratum spinoex, or "priakle cell layer", was superimposed upon the basal layer. ThIo layer oxdinarily had a depth of three to fite calls. The 1dentifialtion of this layer vas simplifled by the abundonce of the intereallwlar bridges between the calls of this son (Mgure 10). The stratum gramlosum was the ouperfletal layer of the meoswn. This sone, which was one cell layer in thicknoss, was readily 1 dentified by the basophtilo kexatohyalin granules which appeared in the ertoplane (Figure 10).

The stratom cornewn of thin skdn ordinarily consisted of the superfleial desatcated cells of the epldemis. The cells, which are nattened and cormified, had frequently lost portion of thetr attachment to the eplthellal layer. Cells of this type ortinarily are classteled as the sealy layer (Figure 8). The Ilattened cell layer may be differentlated from the previous area by the fact that the flattened cornified cells were maintained In a reletively mooth layer.

The cells of the basal layer were usually cubotdal or fustform, sometimes columnar. Those of the stratum spinosum were polyhedral and 
oylindrical bat became incrasingly flattened as the gramulosu was approached (Figures 10 and 11). The metabolic cells of the basale and spinosm layers were generally characterized by an essentially finely granular and IIghtly stained oytoplasm. Tonofibrils were present, espectally in the spinosum. Varying amounts of pigment were evident in the stratum basale and occasionally in the stration spinostan (F1gure 12). Supranacloar caps were frequently observed when plgment was not abundant (Figur 10). Comnecting the Indiridual cells of the "prickle lager" were cytopleanite prosesses thich are camonly referred to as intercellular bridges (Figure 10). The presting cellgw of the gramiowax, raried in quantity, were frattered and angular and contained coarse basophtile keratohyalin granules. They possessed 111-defined mueled and Interoellular bxldges as both were gradvelly becouding obliterated (FIgure 10).

The melet of the basale and spinosum strate were uevaliy vestoular in sppearanee. The rueled of the basul zon were smaller and more elongated than those whioh appeared in the apinoewn, which were uswally spherieal to oval (Migure 11). The muclel of both layers were charactarized by a prowinent molear menbrane, olearly differontiating it from the cytosone. Usnaly two strongly basophlile nuoleoll were present, very often located at opposite poles of the nucleus. Multiform karyosomes situated anong the finer granules of chromatin were observed (Fignre 10).

The epiderwal cells in rarious atages of mitotic activity rarled considerably from the typieal metabolle celle deseribed above. The cells which showed chromosomes were readily identtfied as undergoing mitosis. It 
was possible to 1dentify prophase, metaphase, anaphase and telophsse stages (IIgures 10, 11, 12, 13, 14, and 16). These cells have a clear area about the chromosome mass, which can also be observed provicus to the advent of chromosomes as well as after their dissolution in the reconstruction phase. Those which showed the abore stage are classified as the "chromosomal stages" in the tablos.

A second veriation in the morphology of the diriding opldermal cell was apperent. These onlls were the earlier prophase stages in the process of mat totic division. Typlenlly they exinibited are oondensed, deoply stained, or sometimes fibmillar nucleus whtoh was well demareated by a clear axea of the cytoplass (Figures 15 and 17). Imadiatily about the diaphanous central cytoplan was a thin layer of Iinely gnmular cytoplaem which eppeared to jein the edjecent cells with mumerous intereallwiar bridges. These are the cells which have been designated as the nclear cellan, in the tables.

Still enother rodfleation was the ppearance of cella which were seen in dupliexte. These were continuous along one rargin or were separated by fine plawa mombre which did not show ang orldence, at least in the early stages, of Interellular bridges. All other margins of these culls showed numerous fine cytoplasmic bridges which joined adjacent cells (IIgure 17). The nucleus was variabie in structure appearing as denee basophtitic mass, rather large retieulated chromatin elumps, or approaching what could be termed a vestoular nueleus. A elear or diaphanous zone vas still opparant about the mucleus in the carlier stage of this phase. These cells vere classifled an the reonotruetion cella". 
The posalbility of confusion between "clear cells" and "reconstruotion cellsw, becaube of their morphological similarity at certain stagea, existo (FIgure 17). However, this was minimized by establishing the criterion that melear cells" were obviously single elements, whereas all oelis clasalm fied as reconstructing were present in duplicate. It was still posstble to mistakenly lidentify one member of a reccnstruetion pair for a "elear collu" If the other nember present in a different plane and could not be seen. nolear cella" were not momerous during the day (Figures 1 and 4 Table I), with the exeeption of a 2,00 P.X. deviation at which time $4.46 \pm$ 0.81 pereent of all cello cormted were clessifled in this eategory. The second peak of activit ocenrzed at 12,00 midnight and showed $4.49 \pm 0.49$ percent of the cells in this stage. The peak of Nolear cell" activity usually preceded the peak of the chramescmal stuge" (Figure 4).

It is appartant (Figures 2 and 4 (Table I) that the "chromosomal. stages" of activity were infrequent from 8,v0 N.K. to 10,00 P.H., with the exception of a small incresse at 4100 P.M. It this time $2.89 \pm 0.12$ percent of the cells was observed in the wohromoscmal stages". The pronowned

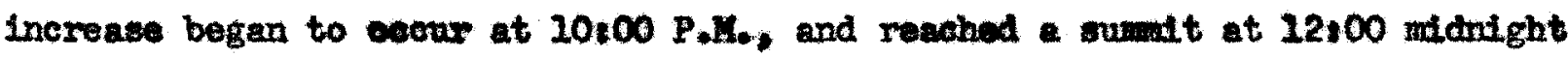
with $6.05 \pm 0.33$ percent of all oells in the typical stages (prophase, motaphase, aphase and telophase) of mitotLe activity unt11 5,00 A.X. when the daliy average aetivity was again epproaohed.

The meximin inorases in the "reconatruetion cells" were attained appraxinately thre hours after the prinary (12,00 midnight) and secondary (4:00 P.M.) "chromosomal stages". At 7,00 P.M. it may be noted that 
$3.29 \pm 0.48$ percent of 211 cells were in this phase. At three olelook in the morning $8.32 \pm 0.91$ percent of the cells observed were elassifled in this ategory (PIgures 3 and 4 ; Table I).

The data indicated that the primary wa approcimately tirice the magnitude of the secondary cyele. (F1gure 7). The sam relationship can iso be observed for the 7,00 P.M. and the 3t00 A.M. reconstruction peaks (FIgure 4). This would indicate that the acoumulation of "reconstructing cells", after each peak of mitotic aotivity, is rather content.

The time nocessary for the complete cyele of cell division, from the advent of the "elear celly to the eppearance of the "reconotruetion cella", was estimated from the oridenee obtained. Pgure 4 indioater that "elear cell" activity showed a gradual progresedve increase at 5,00 P.K. Two hours subsequent to the beginning of this increase almilar phenomenon was evident for the "chromosomal phases". At 9,00 F.M. the beginning of an increment in "reoonstruetion cella" way be observed. This would indieste a lapse of two houre fran the inchoation of "clear cell" activity to the advent of "chromom somal stages" and two additional houre for the advent of the reconstruction inerease or a total of four hour from the beginning of the flrot phase (clear cell) to the beginning of the third phase (reconatruetion cella).

Further evidence to support this is mantested by the "alear cell" Ise seen at 2,00 P.H., followed two hours later (4:00 P.H.) by the secondery "chromoscanl phase" oyele and st1ll three houro later (7:00 P.K.) a peak of "recongtruction cell" activity 18 attatned (Figure 4). The tim interventag between the 2:00 P.M. "elear cell" peak and the 7,00 P.M. reoonstruction peak 
was fire hours. However, the time lapse between the beginning of the Increase in Molear colla" at 2:00 P.M. to the beginning of the 6:00 P.M. increase in "reconotruction cells" was again four hours.

The 12:00 P.K. (aidight) peak in "ohromosomal phase" activity (FIgare 4) is not preceded by a two hour prevlous "clear cell" prodecessor but It does have a reconstruetion pesk following three hours later as was seen during the day. The time elapeing between the begiming of the sharp rise in "chromosomal cells" at 10,00 P.M. and the beginnting of the rise in "reocmstruction cells" at 12,00 P.M. Is again tro hours.

It is postulated from the above orldanes that the total tim rom quired for the complete eyelo of cell division is fran four to five hours. The data, thus far exemined, has considered the fluctuations of the categories into which the provess of cell division has been divided for examplo "olear", "ohrowosomel" and "roconstrueting cella". By combining the date for each of the above categorles the complote mitotile activity for any given hour may be obtelned.

The mejor and minor peaks of mitosis which have been reforred to proviously again are apparant (Fgure 7). In this instance one cannot only observe the increased activity but also the pexicd of time over which the increased activity extends. The minor cycle has a duration of three hours and represented an increase of 100 percent over the average deliy af totlo activity. The mafor cycle, which represents an inc reased activity of almoat 200 percent, extends over a period of six hours. 
The initial increase in the major and minor period is due to Increased mubers of cells in early stages of diviolon - the "eleer cells" (Figures 1 and 4 ). The malntenence of peak of activity is assoclated with the Increased numbers of oells in "chromosonal stages (Figures 2 and 4 ). The peak of the period of roconstruction of the daughter colls (Figares 3 and 4) was primarliy reaponatble for the maintanance of the last portion of the cycle. Another interesting and signifieant phonowens was the locplisetion of cellular divisions tnto that wero designated ts "nests". These were especially proverent during the periods of great ativity. It was not unoommon to find relatively inactive, in so far as cellular divioton was concerned, adjacent regions for quite some distane from these active rogions. In general, however, various stages of division were very easy to recognize, though not as numeroves as in the "nest areas", throughout the epldemis diring peaks of ectivity. This is perhaps the same phenomenon described by Flemaing in 1884 while working on the epidemis of adult rabbits, guinoa pigs and cats, when he described the occurrenee of cells growing "schubwelse", for example, in shifts. It is also quite probable that this meat effect is the same teve which Thuringer (1928) desoribed while working on epidermis of the prepuce. Ho stated, "It was posolble to count as mang as ten to fourteen figares under high power ( I 400 ) in a single field through the conter of a "growth wave", while toward the perlphery of these proliferation centers the number of mitotic flgures would taper off to zero."

Cello undergoing division were not confined to the basal layer, as was once thought, but were seattered throughout the stratum germinativem, 
predominating in the middle and lower regions of the stratum spinsoum and basal legers. During periods of relative inactivity it was observed that the majority of the few dividing cells were confined to the basal layer.

There was no evidence of lymphocyte or of any other mesodermal elements transforming into eplthellal cells. Iymphocytes, usualls confined to the basal lajer, constituted less then one percent of all cells in the epidernis. In only one instance was a rate as high as four pereent observed. They did resemble the "clear cell" in that the nuclel of both were frequently dark and appeared pycnot1c. The nucleus of the lymphocyte was surrounded by an agranular, clear cytoplasm. The opithelial "clear cell", however, showed the presence of an additional rim of finely gramular cytoplasm which was continuous wh adjacent cells by means of numerous intercellular bridges. Ther was also a size varlation, Iymphocytes being $1 / 3$ to $1 / 4$ the diameter of the epithelial "elear cell".

There appeared to be a minor and major peak of cell division. In order to determine whether the same individual followed the shythmic cyole of cell division or not, second and third blopsles were subsequently taken at varlable periods durling the day. The results of this study were tabulated in Table II. The cell mutiplication in practically all instances paralleled that of the overall activity obtained for the specific hourly period. For example if the hour, from which the biopsy was obtained, was rather inactive for the group the same would hold true for the individual and vice versa. The difference in the mitotic cell counts was frequently insignificant. 


\section{Drscusstom}

The traditional coneept of indirect cell-division (mitosis) whieh Includes the prophase, metaphase, anuphase and telophase stages has a definite pedagogical value. Howerer it does not emphasize the cytoplasmie modiflcations which precede, accompan and follow the chromosomal divisions. Observations in this laboratory on the human epiderats, as well as on tissues derived from various other sources, show a "halo" (or elear area) developing about the nuclews in the early phases of indirect cell division. As the karyosomal changes progress through the apireme to the "chromosomal stages", the clear area surrounding the nucleus becomes larger and more distinct. Therefor in our stuty, the cells, which are classifled as "clear cells", represent the early stages of the prophase.

Figure 18 illustrates the clear zone effect in the epiderals of the Amblystoma larra. Here a ntotile figure (metaphase) is seen surrounded by a clear zone. It can be postulated that the clear zone is necessitated by the fact that there will be turbulent nuelear roorganization and it would only seen reasonable that some chenges in the cytoplasmic viceosity would precede karyokinesis. Sharpe (1934) states that cytoplaande Viscosity varies greatly at different stages of cell-division and differentiation. It is believed that the clearing effect can be observed, even more clearly, when vieuing repid motion pictures taken of intosis from tissue culture. 
Statistical analysis offers evidence to support the ralldity of the experimental results. The $P$ values for vlear cell" activity during each of the hours, 11:00 P.K., 12,00 midnight, and 1,00 A.K., was .01, which is very significant (Flgure 5). I datly average, of 1.68 pereent, which was used as the control in the caloulation, was derived from the hours of 2:00 A.M. through 10,00 P.K. The least anount of activity was observed at 1,00 P.X. uth a $\mathrm{d}$ value of 0,40 (rable I). Another enalyols relating to the 2,00 P.M. Increment in "clear coll" activity manifested a $P$ value of .02 (Migure 6). The datly arerage, of 1.53 pereent, was obtatnod from the hours of 3,00 P.H. through 1,00 P.H., exclusive of the 21,00 P.M., 12:00 mldnight, and 1,00 A.K. hours.

The "chromosomal cell" peaks at 11,00 P.M., 12:00 midnight, and 1,00 A.M., were caloulated againat a daily art thmotical mean of 1.44 obtained from the same hours as the aforemantioned "clear celle", rovealed a $P$ ralue of .05 , .01 and .01 respectively (Figure 5). The smullest d valuo for ang one hour in the control 0.26 (Table I). The secondary mitotic eyele at 4,00 P.M. possessed a $P$ value of .01 (PIgure 6). Th1s was calculated againat a control with an arithmetical mean of 1.36 ohtained from the hours of 5.00 P.M. through 3,00 P.M., exelnstre of the peak hour of 11,00 P.K., 12,00 midnight, and 1,00 1....

Another signiflcant $P$ value of .01 was obtained for both the 2,00 A.M. and 3,00 A.M. reconstruction increases in actirity (Flgure 5). The duily average with an arithmetical mean of 2.42 was obtained from the houre betwoen 4:00 A.M. through 1,00 A.M. The amellest $\mathrm{d}$ value was seen at 1:00 P.M. and 
had a value of 0.51 . The 7:00 P.M. increase in reconstruction activity had a $P$ value of 0.2 (Figure 6). This was caleulated against a daily average with an arfthmetical mean of 2.42 obtained from the hours 8,00 A.K. through 5,00 A.M., exclustre of the 2,00 A.M. and 3,00 A.M, peak hours.

The results of the calculations of the stendard deviation are best explained in Table I. The variation that does exist seews to be associated with the degree of activity. Whenever considerable activity occurs the standard deviation 18 a littie higher. This could be due to the diffieultios encountered in identifieation. The data which has been clessified as "chrowo samal cells" revenled the most algnificant results, and Ifkeidse were the least variable for the speciflod perlode. This may be explained by the fact that the cells containfing ohremoemes were pable of postitre identiflcation whereas the volear" and "recongtraction phates" could present classification diffloulties. For examplo a call 1dentified as a "clear cell" could concelvably be a member of reconstructing palr with the other member missing because of 1 ts position in another plane or section. The inferenee would seem to follow that variation in the "ehromosomal cells" would perhape resemble more closely blological variation whereas the "clear" and "reconstruction cells" would be blologieal plus the larger orror of identification. It must further be noted that the "nest" effect would be conducive to variation as the two strips meacured, with no atterpt to take into consideration the number of "nests" in the particular strip. If the number of "nests" in all strips were equal then there would be less chanee for rariation. It is coneluded that the standard derlation is quite low when all factors which 
could Induce error are considered.

It is apparent that there are two peaks of activity insofar as "chromosome atages" are concerned. One oocurred durlng the day at 4:00 P.X. (minor cyelo) and the other at 12,00 minight (major cyole). The major cycle has approximately tules the magnt tude of that seen during the minor cyole. The same for the most part, is true of the clear and reconstruction activity. When all three types of cells are combined notice that the unor oycle had a duration of three hours and show an increase of 100 pereent in mitotis activity over the daily arerage. The majer oyele, which represents an increase in activity of almost 200 pereent, cxtonded over a period of six hours. It is obvious that the majortty of the actirity tukes place at night, which Broders and Dublin, as well as Cooper and Schtef, had observed from thetr operee sampling. This, of course, is just the opposite to that of the epidernds of the rat or mouse.

Our evidence Indicates that the epldermal replacement mochanion is mitotic activity and It further explains wh the impreasion of a relative laok of mitotic figares has been stated in the Ilterature. It is donbtful that mach thasue was taken from individuals for rontine examination during the hours of maximm mitotic activity. It is more probable that the majority was teken during the late morning hours when activity was at lts lowest ebb.

It is not possible, at this tire, to offer explanation as to why a dinmal periodieity exists. Certainly it is gafe to assume that any study of physiological factors whtch are considered to be wtogento or of mitotic indices, would necessarily be more valld if this perlodicity were 
given conbideration. Several phyoiologioal factors have been Investigated by Bullough (1948) in relation to the mitotic periodiolty in mice. He roported an increase in epidermal glyoogen content during wleep, when the antothe rate Incresses. With the onset of sleep glucose is deposited from the blood into the tissues where it appears in the form of glyeogen. On awakening the reverse process takes place. He conslder this glucose or glveogen to be the oritical substanoe affecting mitotio activity in the adult mouse. Bullough further stater. that there seened to be no reason to doubt that the samo would be equally appliabile to man. If this is the case in $\operatorname{man}$ it is not the orset of sleep itself that is responstble for the depesition of the glucose Into the epldermis because the mafortty of the night volunteers had not slept prior to presenting themselves for biopsy. This was espectally true for those majecting themselvas to biopsy dueing the peak perlod of activity. Bullough also reported that excesalve muecular exerelse is followod by an abnormal depression in iftotic rate. In this study the evening rolunteer were for the most part more active prior to giving tissue than they were dur Ing the earlier hours of the day as man of then engaged in recreation in the nearby gymasium, as they awatted their turn, while during the day the majority spent thelr time sitting in the clessroom.

Certainly an investigation of the glycogen content, effect of enviromental temperature, seasonel changes, posstble evidence of auclear protein synthesis plus the possibjitty of a reversal in this periodicity are worthy of investigation. One conterplated way of approsching the possibility of a reversal is to secure biopsies from individuals who have reversed their 
sleeping hablts, such as night worker in factorles.

One con conclude that the eyelte diurnal periodicity is an witsmate expression of certaln mitogentc factors, whether they be hozmonal, mitrition, temperatare, enviromental, physiological state, age or sex.

In an study of mitogente factors or of mitotio indices the rellam bility would seen to necessertily depend on the consideration given to the periodicity.

\section{sonath}

1. The replacement or increase of the epithellal cells in the trman epiderads 18 accomplished by mitosis. This mitotic activity occurred in datly oycles.

2. Thre major categorles of eells, within this mechaniom of cellular divialon have been deseribed. They are flrst the "clear cell" which Is characterized by an Inner clear zone in the cytoplasm which makes Its appearance before major nuclear reorganfration takes place and remains until the daughter cell has attainod maturito, at which timo 1t disappears; secondly, the typleal "chromosome stages" (prophase, metaphase, anaphase and telophase) and finally the "reconstruction cell" which is present in duplicate and is 14kewise characterized by the clear zone mentioned above.

3. The three types of cells manifest a primary and secondayy dally rhythm in thelr occurrence. The primary rhythm for the "clear cell" attains 
1ts peak at 12:00 midnight and has a value of .01 whioh 1s very significant. The secondary occurs at 2,00 P.M. and, though not as significant, 1t does have a P value of .02. "Chromosomal cells" are highest at 12,00 midnight and have a very significant $P$ value of .01. The secondary mitotic eyele oceure at 4:00 P.M. and 1t 2leo has a $P$ value of .01. The "reconstruction cell" attains madmem magnitude at 3,00 A.M. and has a $P$ value of .01 which is very oigntfloant. The minor cycle for "reconstruction cells", oceurring at 7:00 P.M., becaube of its $P$ value of 0.2 , cannot be considered signirleant as the level of signifloance was established at .05.

4. When cambining all three types of cells the major cycle manffested an Increased activity of almost 200 percent over the dafly average and extended over a period of six hours. The minor cycle had a duration of three hours and represented an inerease of 100 percent in mitotie activity.

5. The approximate time for a cell to difide, based on the appearance and activity during the twenty four hour period, of the three categories of cells has been estimated at four to five hours. For axample, "elear cells" precede "chromosomal ce.lls" by two hours and reconstructions follow the "chramosomel phase" by approximately two hours.

6. Cellular division frequently ocourred in localized regions designated as "nests" and often were surrounded by relative inactive adjacent regions. This was especially true during perlods of great activity. 
7. Cello undergoing division were most frequently observed in the middle and lower rogions of the stratum spinosum and basale, during periods of high activity. During relatively inactive periods the mafority of the mitotic elgures in the basal layer.

8. There was no evidence of lynuphocyte or of any other mesodermal elements transforming into opithelial cells. 


\section{BIBLIOGRAPHY}

1. Andrew, W., and I. V. Andrew, 1949. Lymphooytes in the norral epidermats of the rat and of man. Anat. Reo., Vol. 104, pp. 227-2hl.

2. Bablak, R., 1951. The effocts of parenternl injections of cortisane on attotic activity. M. A. Thesis, Loyola Onir.

3. Blumenfeld, O. M., 1939. Periodic mitotic activity of the epidermis of the albino rat. Seience, 701.90, pp. 4li6-447.

4. Blumenfeld, C. M., 1942. Comparison af periodic mitotic activity in the epldormis, renal cortex and submaxillary salivary gland of the albino rat. Arch. Path., Vol. 33, pp. 770-776.

5. Bostroem, B., 1928. Der Krobs des Menschen. Loipsigt Georg Thiene Verlag.

6. Broders, A. C. and W. B. Dublin, 1939. Phythmilesty of mitosis in the epldermis of human beings. Proc. Steff Meet. Mayo Clinto, vol. 14, pp. 423-425.

7. Bullough, W. S., 1947. Mitotic activity in the advit male mouse. The diurnal cycles and their relations to waing and sleeping. Proc. Roy. Soe. B., Vol. 135, pp. 212-232.

8. Bullough, W. S., 1948. The effects of experimentally induced rest and exercise on the epidermal mitotio activity of the advit malo mouse. Mas muscuing. Proo. Roy. Soc. London, 8. B., Vol. 135, pp. 233-242.

9. Bullough, W. S., 1949. The effeets of high and low temperature on the epidermal witotic activity of the edult mouse. J. Exper. Biol., Vol. 26, pp. 76-82.

10. Bullough, W. S., 1949. The relation between epidermal mitotic activity and the blood sugar level of the mouse. Mus museulus. $J$. Bxper. B101., Vol. 26, pp. 83-89.

11. Bullough, W. S., 1951. Epidermal mitotic activity and oxygen tension. Vature, Vol. 167, pp. 488. 
12. Bullough, W. S. and C. J. van Dordt, 1950. The mitogenic sotions of testosterone proplonate and of oestarone on the epidermila of the advilt mele mouse. Acta endocrinol., Vol. 4, pp. 291-305.

13. Cameron, J. H., 1936. The origin of new epldermal cells in the skin of norral and I-rajed frogs, J. Morph., Vol 59, pp. 327-350.

14. Carleton, A., 1934. A rhythmical periodicity in the mitotic divialon of antial cel2s. J. Anat., Vol. 68, pp. 251-263.

15. Cooper, Z. K. and H. C. Frankl13, 1940. Mitotic rhythras in the ep1dermis of the mouse. Anat. Rec., Vol. $78, \mathrm{pp} .1-8$.

16. Cooper, Z. K. and A. Sohtf,, 2938. Hitotio rhythes in human epidernals. Proc. Soc. Exp. Biol. and Yod., Vol. 39, pp. 323-324.

17. Blliott, H. C., 1936. Studies on articular eartilage. I. Growth mechaniams. In. J. Anat., Vol. 58, pp. 127-2117.

18. Fortwan-van Leyden, D., 1916. Some observations on perlodic nuclear division in the cat. Proe. Akad. wot. Ansterdam, Vol. 19, pp. 38-44.

19. Fortuym-ran Loyden, D., 1926. Dey and night period in nuclear division. Proc. Akad. wet, Amsterdam, Vol. 29, pp. 979-988.

20. Frleboes, W., 1920. Beltrage zur Anatore und Biologie der Hant. II and III, Dermat, Ztachr., Vol. 31, pp. 57-83 and Vol. 32, pp. 1-10.

21. Halberg, H., et el., 1954. Dafly variation in tissue mitosis, blood cosinophis and rectal temperature of rats. Am. J. Physiol., Vol. 177, pp. 361-366.

22. Rarsten, G., 1918, Ueber Tagesperiode der Kern-und Zelltellung, Zeit. f. Bot., Vol. 10, pp. 1-20.

23. Kellicott, W. B., 1904. The dally periodicity of cell division and the elongation in the root of Allium. Bull. Tory. Bot. Club, Vo1. 31, pp. 529-550.

24. Loblond, C. P. and B. E. Walker, 1956. Fenewal of cell populations. Phyo101. Rev*, Vol. 36, pp. 255-276.

25. Levander, 0., 1950. On the epithelium-regeneration in the healing of wounds. Act chir. Scandinar., Vol. 100, pp. 637-649. 
26. Milletti, A., 1950. Le Htmicita glomaliera dell' attivita mitotica studiate sugli elementi midollari. Arch. Itel. Anat. Enbriol., Vol. 54, pp. 339-351.

27. Pinkus, H., 1953. HLology of epldermal cello. Physiology and Biochendstry of the Skin, Rotham, S., Univ. of Chicago Press, pp. 586-588.

28. Ortiz-Picon, J. M., 1934. ïber zelltellungafrequene und zellteilungsrhythmes in der Hpidernis der kaus, ztsehr. F. zellforseh u. mikr. Anat, Vol. 19, pp. 488-509.

29. Sharp, L. W., 1934. Introduction to Gytologs. 3rd od. Mecraw-li111, p. 31.

30. Stelfelt, M. G., 2921. Stud. über die Periodizitat d. Zellteilung u, alck daran ansehllessende Ersohelnungen. Kunot. Svensks Vetensh. Hend., Vo1. 62, pp. 1-114.

31. Sutton, R. L. Jx., 1938. Barly opldermal neoplasias description and interpretation. Aroh. Dermat. \$yph., Vol. 37, pp. 737780.

32. Thuringer, J. M., 1924. Regeneration of strat1fied squamous cell epithaitum. Anat. Rec., Vol. 28, pp. 32-38.

33. Thurlinger, J. M., 1928. Studtes on cell diviaton in the hwan epidermis. Anat. Ree., Vol. 40, pp. 1-13. 
TA B L E S 
TABLS I

HOURY AFITHEETTOAL MEAF OF CLBAR, CHROMOSOMAL AND RECOSTHWOTION GELIS WIZH STAMMARD DEVIATIOA

\begin{tabular}{|c|c|c|c|}
\hline HOUR OR DAT & CLEAR CRUIS & CHROMOSOAAL PHASE & RRCOUSTRUCTION GELS \\
\hline 8.00 A.llt. & $1.05 \pm 0.22$ & $1.13 \pm 0.22$ & $3.59 \pm 0.54$ \\
\hline 9000 A.K. & $1.43 \pm 0.14$ & $0.45 \pm 0.08$ & $2.79 \pm 0.42$ \\
\hline $10100 \mathrm{A.H}$ & $0.65 \pm 0.07$ & $0.62 \pm 0.16$ & $1.01 \pm 0.18$ \\
\hline 11,00 A.H. & $0.61 \pm 0.07$ & $0.26 \pm 0.04$ & $0.66 \pm 0.15$ \\
\hline $12,00 \mathrm{A.H}$. & $1.19 \pm 0.12$ & $0.92 \pm 0.15$ & $1.26 \pm 0.16$ \\
\hline I:00 P.K. & $0.40 \pm 0.08$ & $0.37 \pm 0.07$ & $0.51 \pm 0.08$ \\
\hline $2: 00$ P.H. & $4.46 \pm 0.81$ & $1.45 \pm 0.30$ & $4.25 \pm 0.66$ \\
\hline $3,00 \mathrm{P} . \mathrm{K}$ & $2.20 \pm 0.45$ & $1.50 \pm 0.29$ & $4.27 \pm 0.83$ \\
\hline 4100 P.M. & $2.06 \pm 0.03$ & $2.89 \pm 0.12$ & $3.35 \pm 0.11$ \\
\hline $5: 00$ P.M. & $1.33 \pm 0.35$ & $2.26 \pm 0.17$ & $2.02 \pm 0.58$ \\
\hline 6.00 P.स. & $1.35 \pm 0.15$ & $0.70 \pm 0.12$ & $2.42 \pm 0.32$ \\
\hline $7: 00$ P.M. & $1.65 \pm 0.21$ & $1.00 \pm 0.23$ & $3.29 \pm 0.40$ \\
\hline 8:00 P.K. & $1.27 \pm 0.18$ & $1.14 \pm 0.09$ & $1.85 \pm 0.43$ \\
\hline 9:00 P.M. & $1.68 \pm 0.26$ & $1.23 \pm 0.07$ & $1.89 \pm 0.23$ \\
\hline 10:00 P.K. & $1.28 \pm 0.31$ & $2.44 \pm 0.42$ & $1.94 \pm 0.67$ \\
\hline 11,00 P.M. & $3.19 \pm 0.44$ & $2.61 \pm 0.37$ & $1.49 \pm 0.44$ \\
\hline 12,00 P.H. & $4.49 \pm 0.49$ & $6.05 \pm 0.33$ & $1.54 \pm 0.49$ \\
\hline
\end{tabular}


TABLI I-contimued

\begin{tabular}{|c|c|c|c|}
\hline HOUR OR DAI & CLRAR CRLS & crmorasomal PHAST & REDONSTHCTIOU CELIS \\
\hline 1,00 A.Y. & $3.59 \pm 0.55$ & $4.86 \pm 0.39$ & $2.91 \pm 0.45$ \\
\hline 2:00 A.X. & $3.15 \pm 0.57$ & $3.02 \pm 0.36$ & $4.75 \pm 0.61$ \\
\hline $3 t 00$ A.X. & $3.08 \pm 0.08$ & $2.97 \pm 0.25$ & $8.32 \pm 0.92$ \\
\hline 4:00 A.M. & $2.37 \pm 0.32$ & $2.05 \pm 0.26$ & $4.18 \pm 0.17$ \\
\hline 5,00 A.M. & $1.87 \pm 0.29$ & $2.00 \geq 0.33$ & $4.12 \pm 0.41$ \\
\hline
\end{tabular}


TABLS II

COMPARISOY OF PERCBMTAGRS FOR BIOPSTES FROM SAME INDIVIDUAL WITH HOURLY AVRRAGR

\begin{tabular}{|c|c|c|c|c|c|c|}
\hline \multirow{2}{*}{ 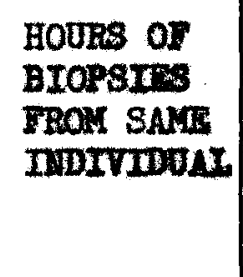 } & \multicolumn{2}{|c|}{ CLEAR GRTIS } & \multicolumn{2}{|c|}{ CEROMOSOMUL PLASR: } & \multicolumn{2}{|c|}{ REConstruexIou chIs } \\
\hline & Percent & $\begin{array}{l}\text { Compared } \\
\text { with datzy } \\
\text { average }\end{array}$ & Pereent & $\begin{array}{l}\text { Compared } \\
\text { udth daily } \\
\text { average }\end{array}$ & Perent & $\begin{array}{l}\text { Compared } \\
\text { with daily } \\
\text { average }\end{array}$ \\
\hline 11,00 P.X. & 3.28 & 3.19 & 2.66 & 2.61 & .69 & 1.49 \\
\hline 1,00 A.M. & 3.55 & 3.59 & 7.35 & 4.86 & 2.38 & 2.97 \\
\hline 5,00 A.K. & 3.05 & 1.87 & 2.29 & 2.00 & 4.35 & 4.12 \\
\hline 10,00 P.A. & 1.02 & 1.31 & 2.61 & 2.44 & .41 & 1.80 \\
\hline 12,00 P.H. & 5.07 & 4.49 & 6.12 & 6.05 & 1.24 & 1.54 \\
\hline 5,00 A.K. & 2.09 & 1.87 & 1.12 & 2.00 & 2.09 & 4.12 \\
\hline 9,00 P.X. & 1.38 & 1.63 & 2.01 & 1.23 & 2.04 & 2.94 \\
\hline $1,00 \mathrm{~A} . \mathrm{X}_{0}$ & 3.44 & 3.59 & 5.55 & 4.86 & 2.78 & 2.97 \\
\hline 4,00 P.I. & .71 & 2.37 & 2.95 & 2.05 & 3.49 & 4.18 \\
\hline 4,00 P.X. & 1.13 & 2.37 & 1.95 & 2.05 & 3.65 & 4.10 \\
\hline 8.60 P.H. & .84 & 2.13 & 1.16 & 1.14 & .69 & 1.98 \\
\hline $1,00 \mathrm{~A}, \mathrm{H}$. & 3.44 & 3.59 & 5.55 & 4.86 & 2.78 & 2.97 \\
\hline 12:00 P.A. & 3.81 & 4.49 & 5.01 & 6.05 & .76 & 1.54 \\
\hline 10,00 P.K. & 1.72 & 2.31 & 3.02 & 2.44 & 1.83 & 1.80 \\
\hline
\end{tabular}


TABLS II-continued

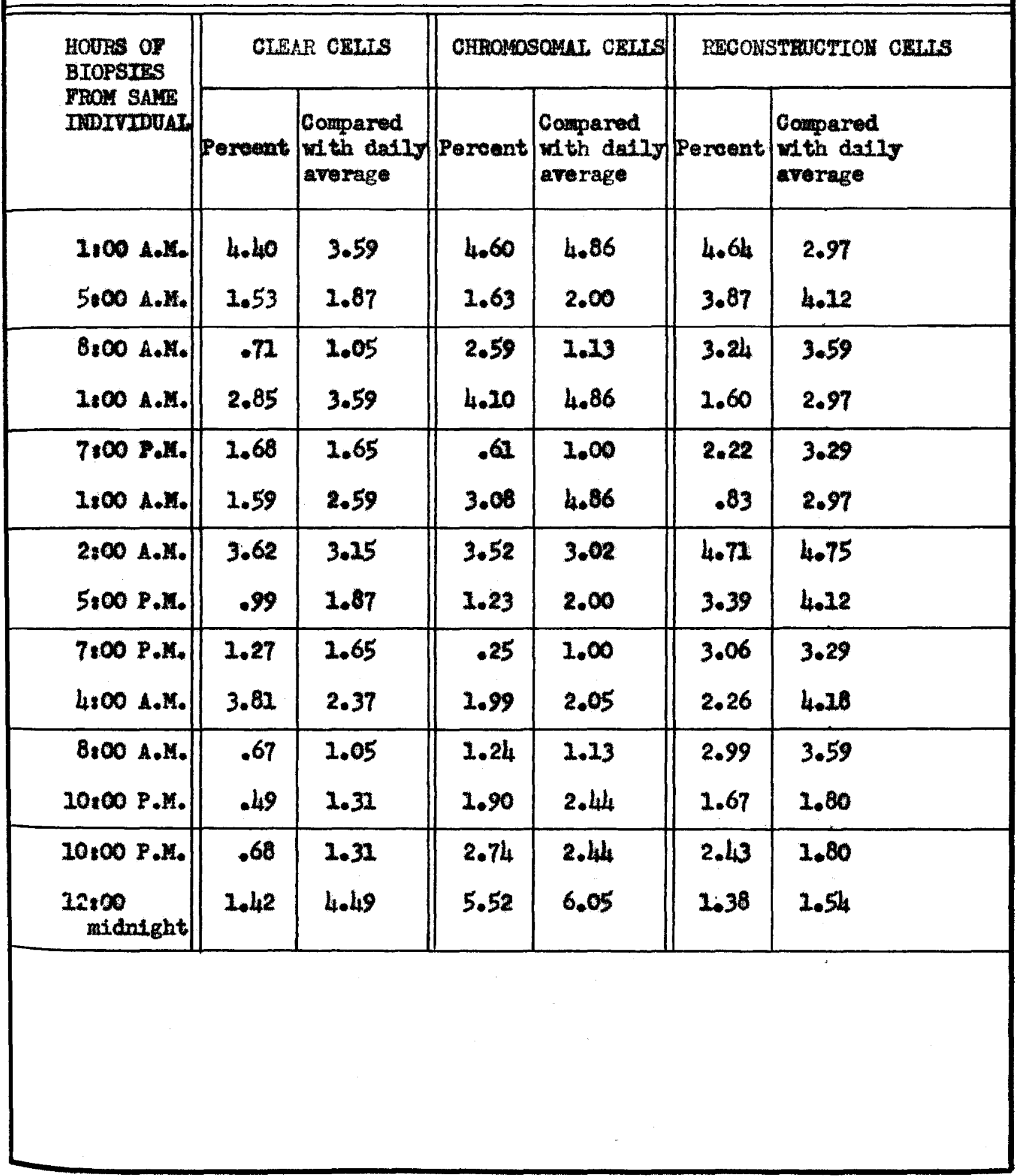


FIGURES AND PIATES 
Figure 1. Variation in clear cell activity during the twenty four hour period.

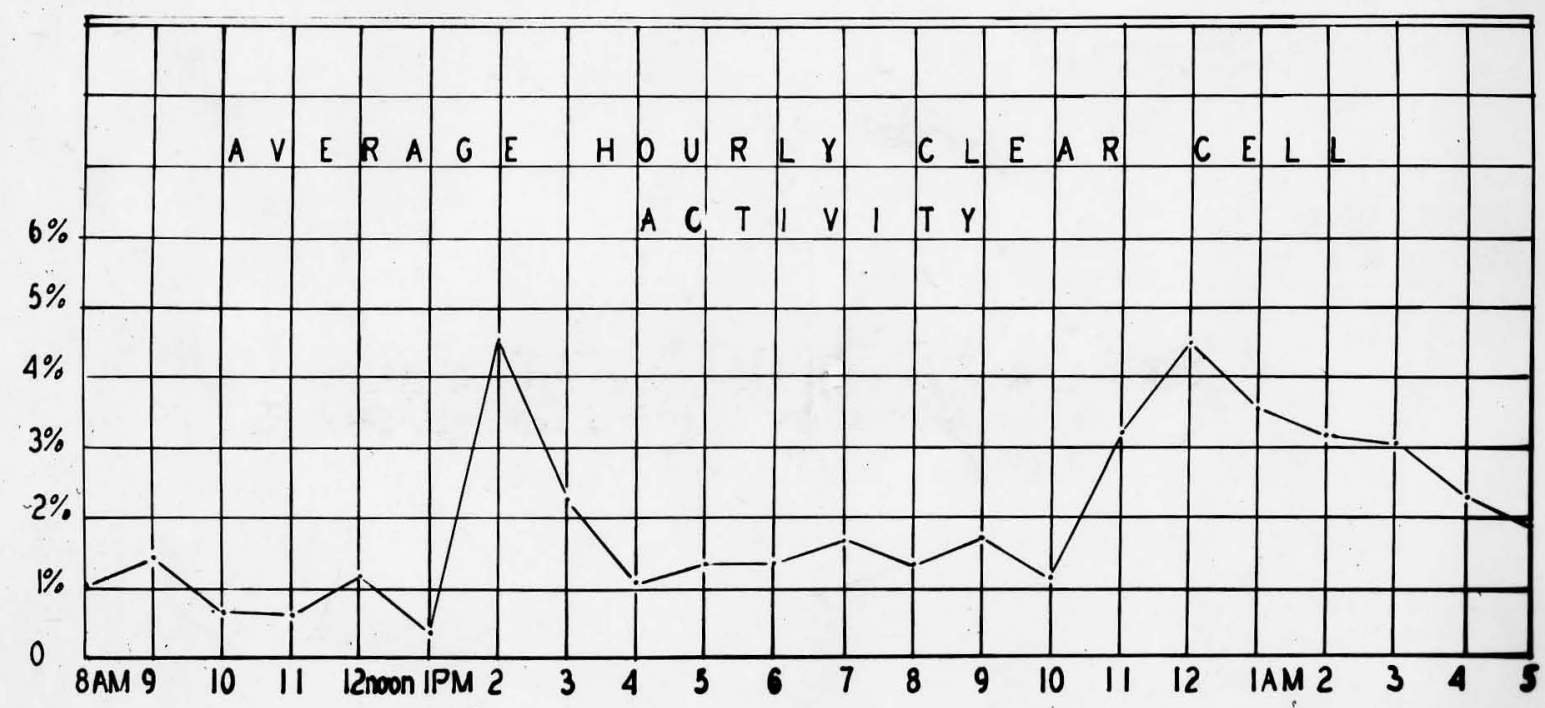

Figure 1 

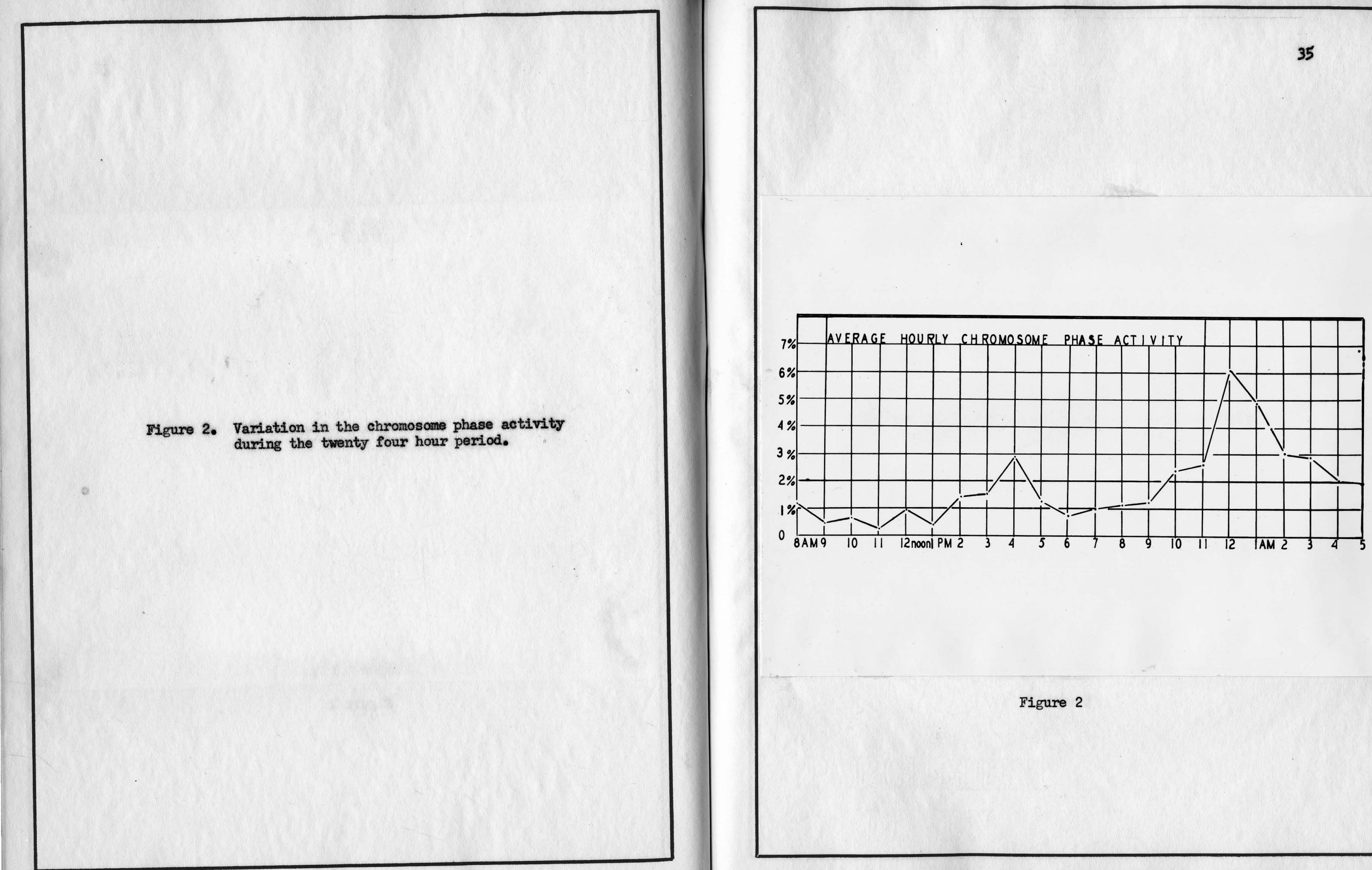

Figure 2 
Figure 3. Variation in reconstruction cell activity during the twenty four hour period.

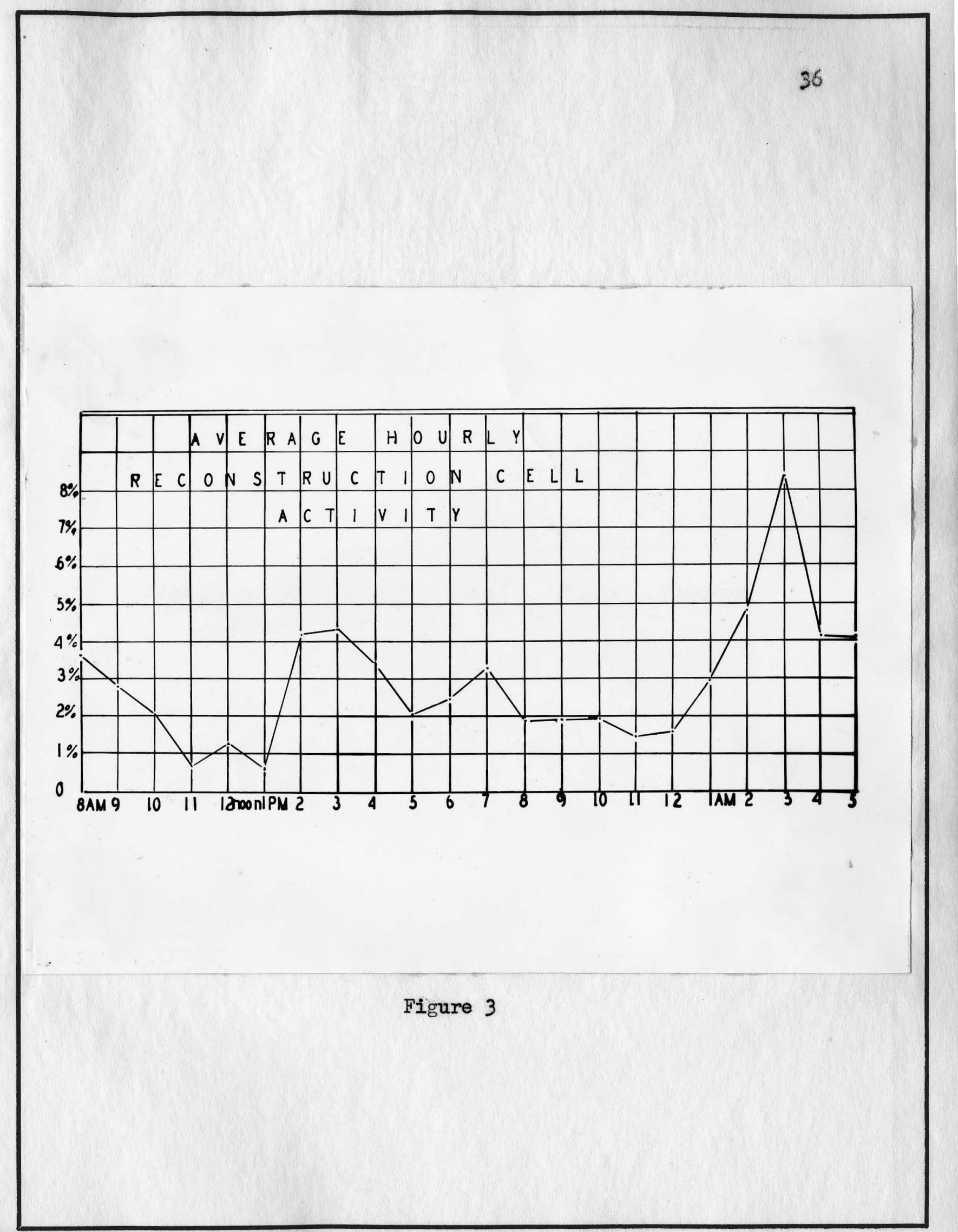


Figure 4. Variation in the activity of clear, chromosomal and reconstruction celis.

clear cells

-..........- Chromosomal cells

.......... Peconstruction

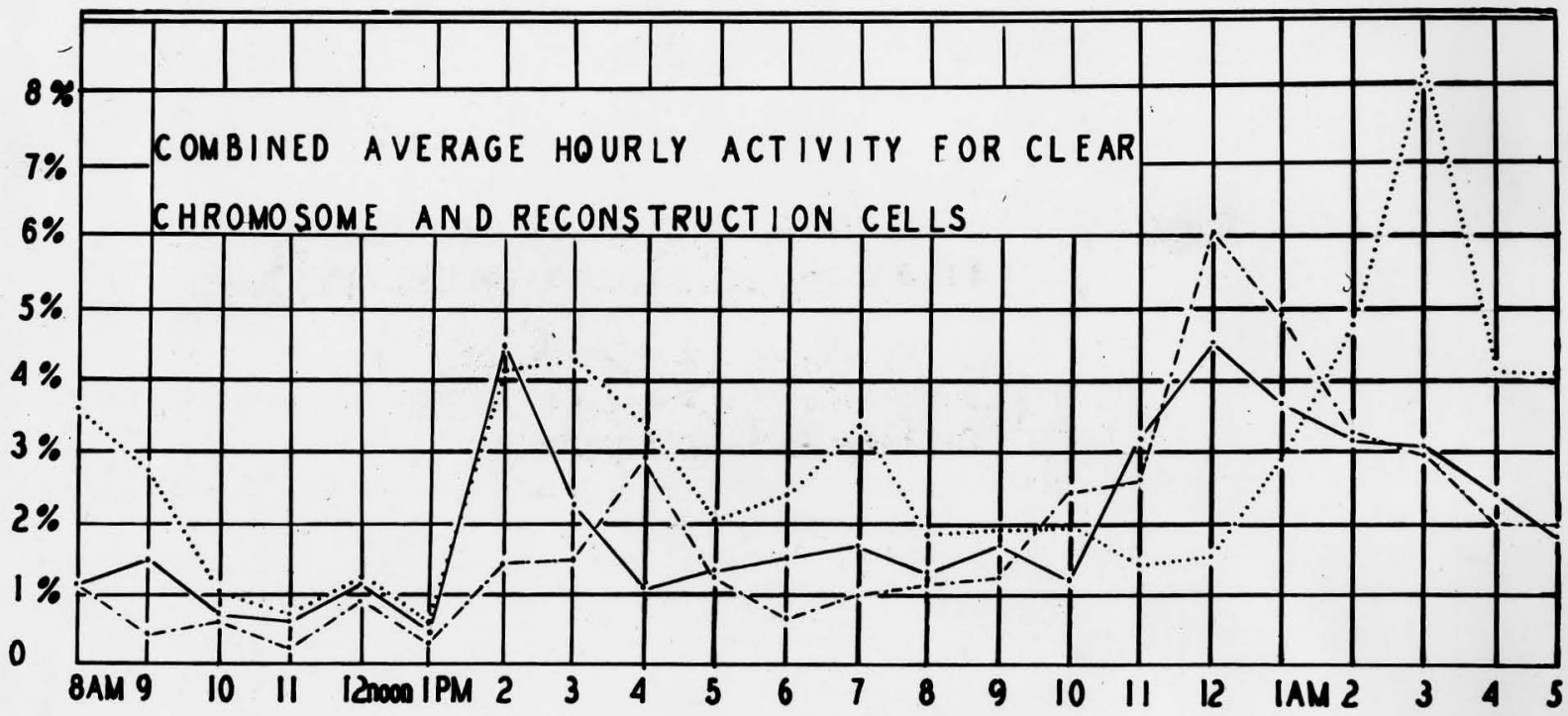

Figure L 
Figure 5. Statistical values of the major peaks of activity for clear, chromosomal and recon struction eells. The numerical values 3.15 , 3.02 and 4.27 indicates the maximum percenthe tage activity ased to calculate the dally average. Like0.5 the nute the 0.5 indicate the lowest percent of activity during this same period.
STATISTICAL VALUES OF

PRIMARY CYCLE

$7 \%$

$6 \%$

$5 \%$

$4 \%$

$3 \%$

$2 \%$ $1 \% 3.15$

$0 \quad 0.4 p=0.1 p=0.01 p=.01$ Ddily 11001200100 Avg PM PM AM

CLEAR CELLS

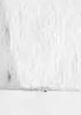

\subsection{2}

$0.26 p=05 p=011 p=.01$ Daily 11001200100
Avg PM PM AM

CHROMOSOME PHASE

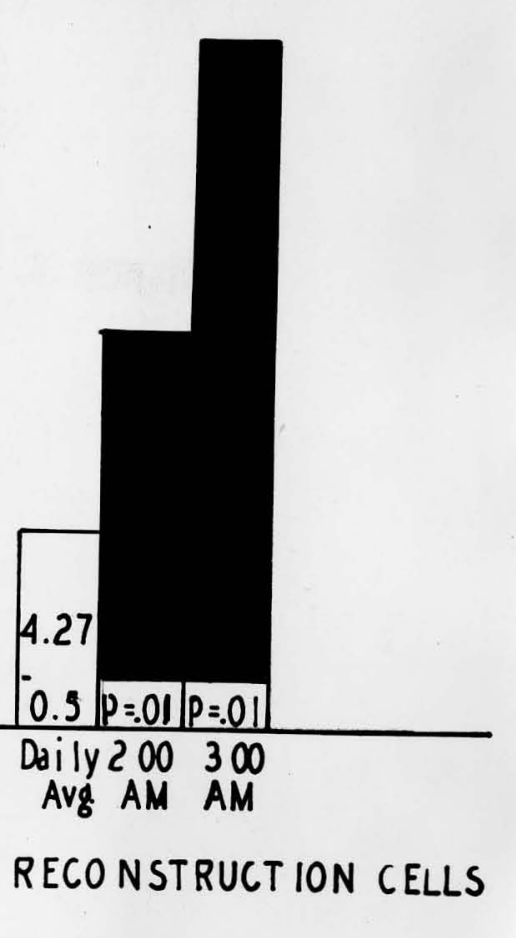

Figure 5 
Figure 6. Statistical values for secondary peaks of activity for clear, chromosomal and reconstruction cells.

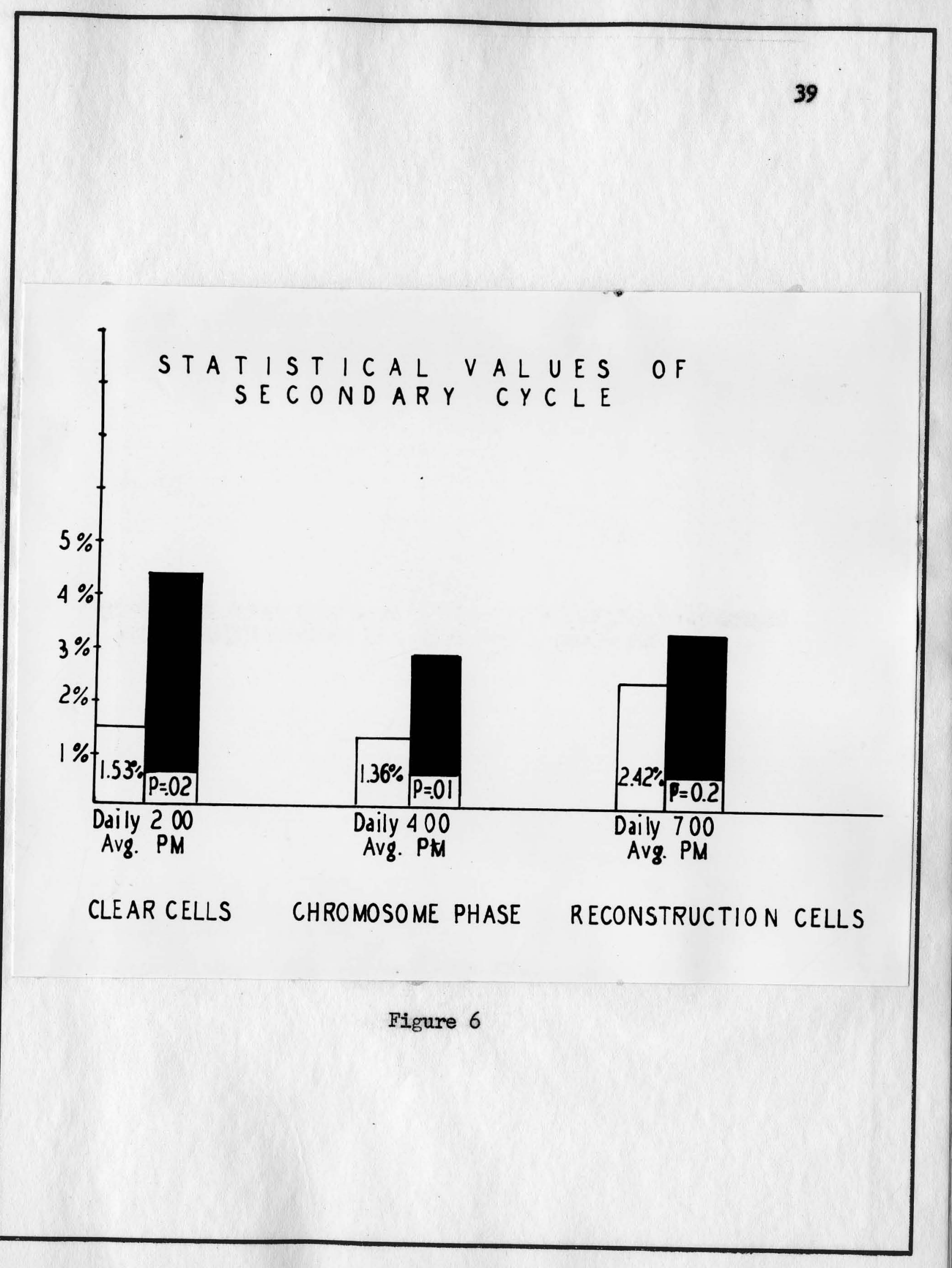


Figure 7. Graph represents total hourly activity for clear, chromosomal and reconstruetion cells.

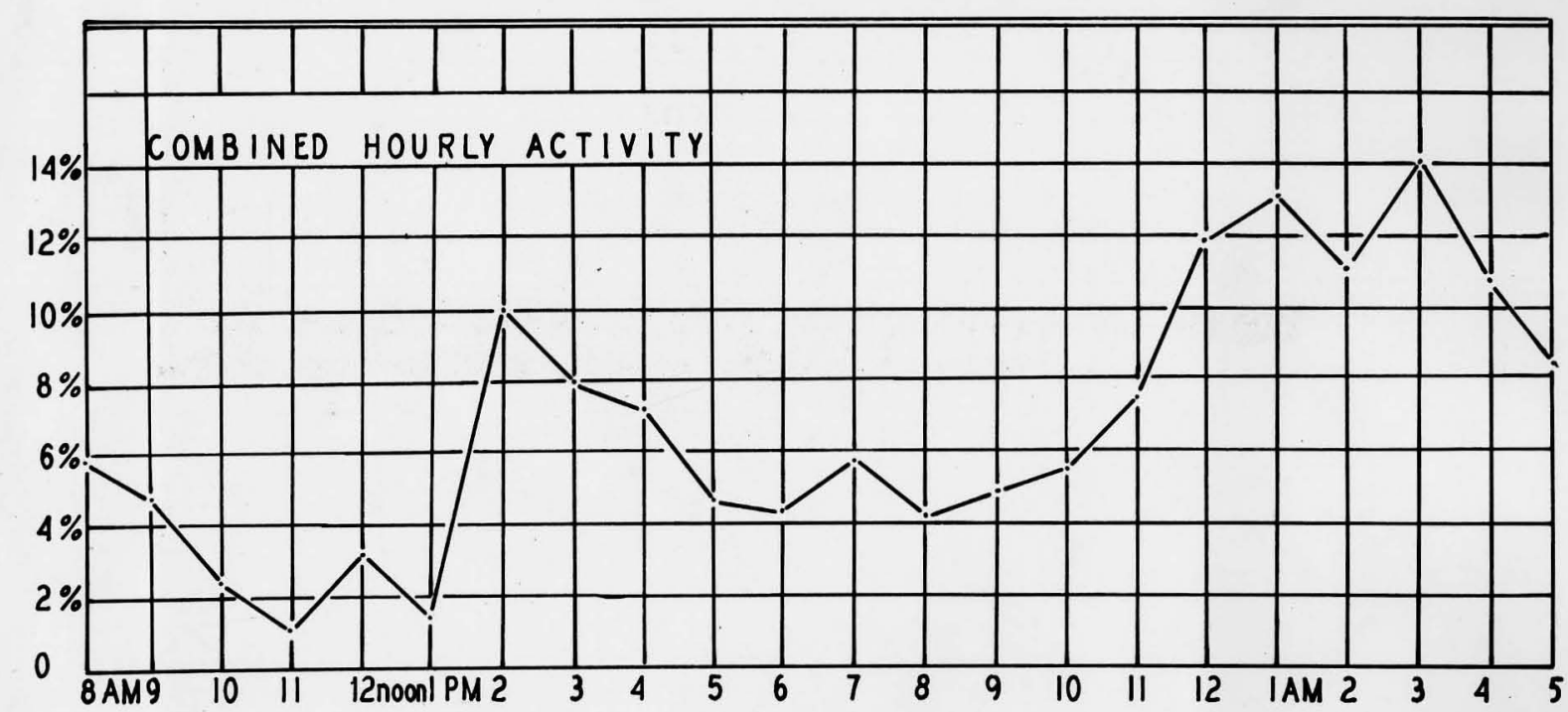

Figure 7 
PLATE I

Abbreviations:

A. - Stratum corneum (scaly layer)

B. - Stratum germinativum (mucosum)

C. - Dermis

D. - Sebaceous gland

E. - Hair follicle

Figure 8

Human epidermis. Note two main layers of epidermis superimosed on the dernis? the stratum corment hatr

sebaceous gland. 75x. All photomicrographs are material fixed in Bouin's fluid and stained with iron Hematoxylin.

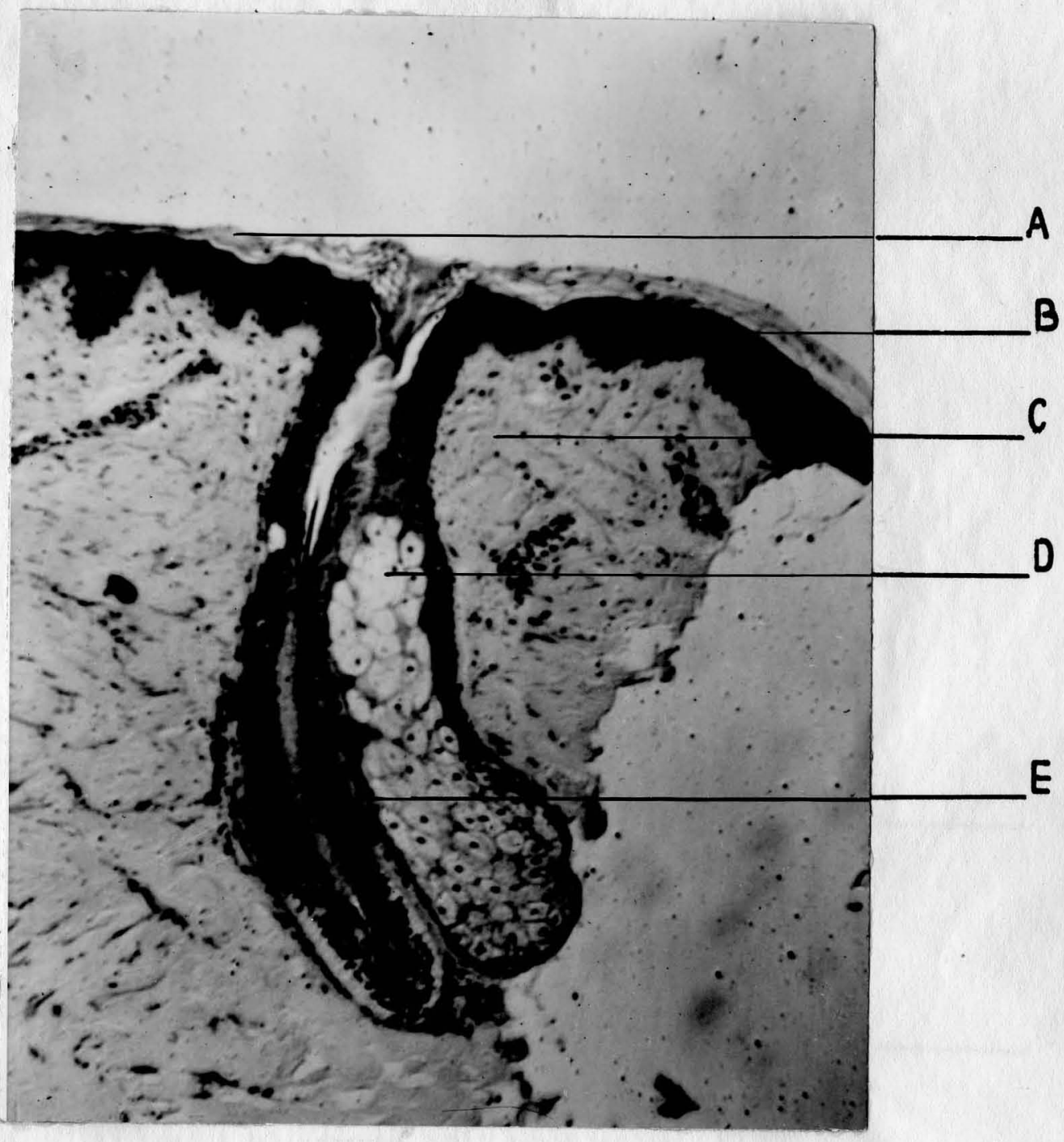

Figure 8 
PLATE II

\section{Abbreviations:}

A. - Basenent membrane

B. - Dermis

Figure 9

Human epidemis. Note basement membrane separating the basal processes of the cells of the stratum basale from the dermis $1900 x$.

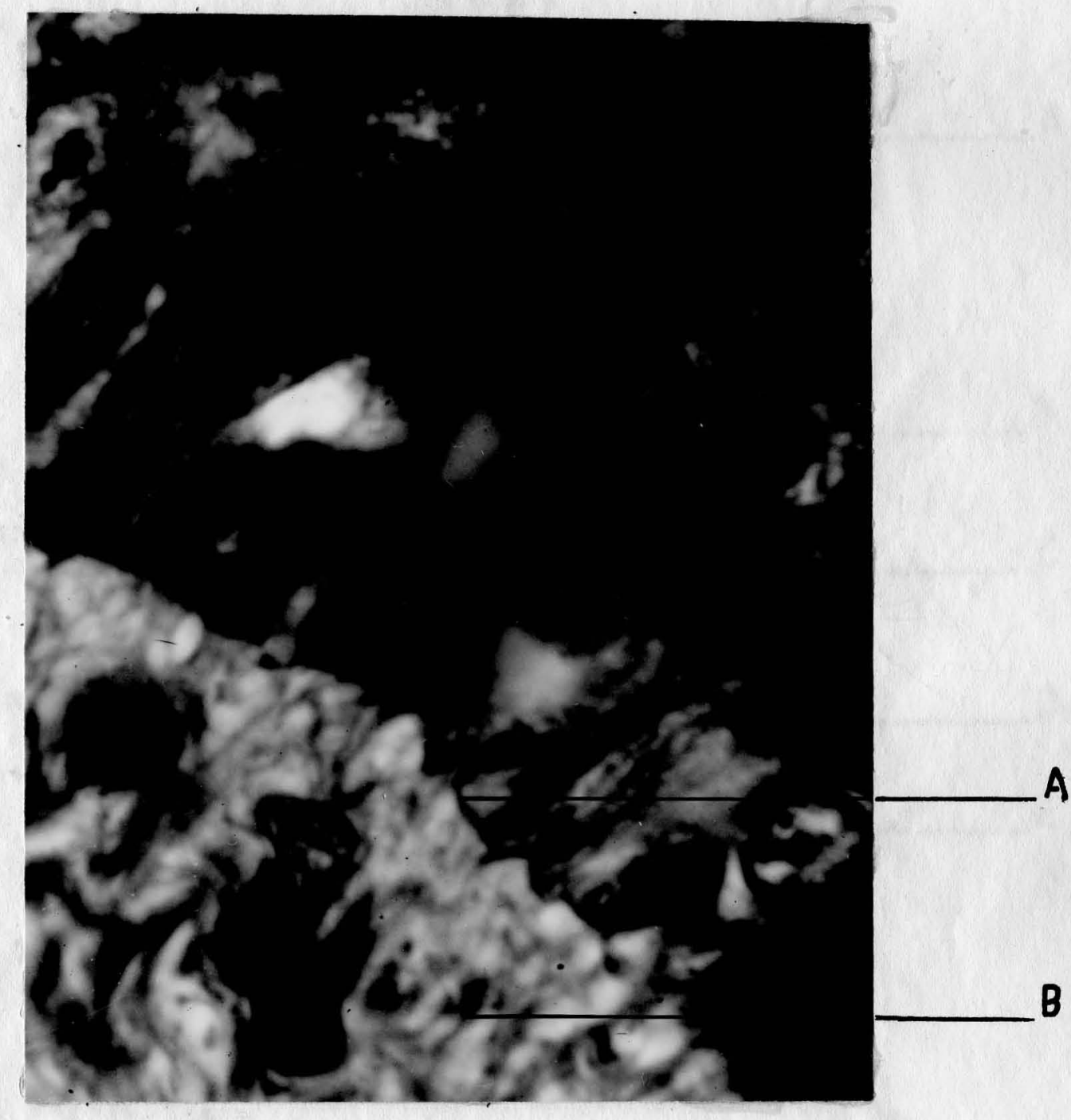

Figure 9 
PLATE III

Abbreviations:

A. - Stratum granulosum

B. - Hucleoli (two)

C. - Intercellular bridges

D. - Supra nuclear caps

B. - Karyosomes

Figure 10

Wuman apiconts. Note stratum basale with supre Hul over nuclei, stratum geminativum nuclear caps over nuclei, stratum gemdinativin nuclear membrane, multiform karyosomes, prominent basophilic nucleoli, and intercellular

bridges. Note early prophase in lower spinosu

showing clear zone and rim of cytoplasm con-

necting to other cells of the spinosum. 1900x.

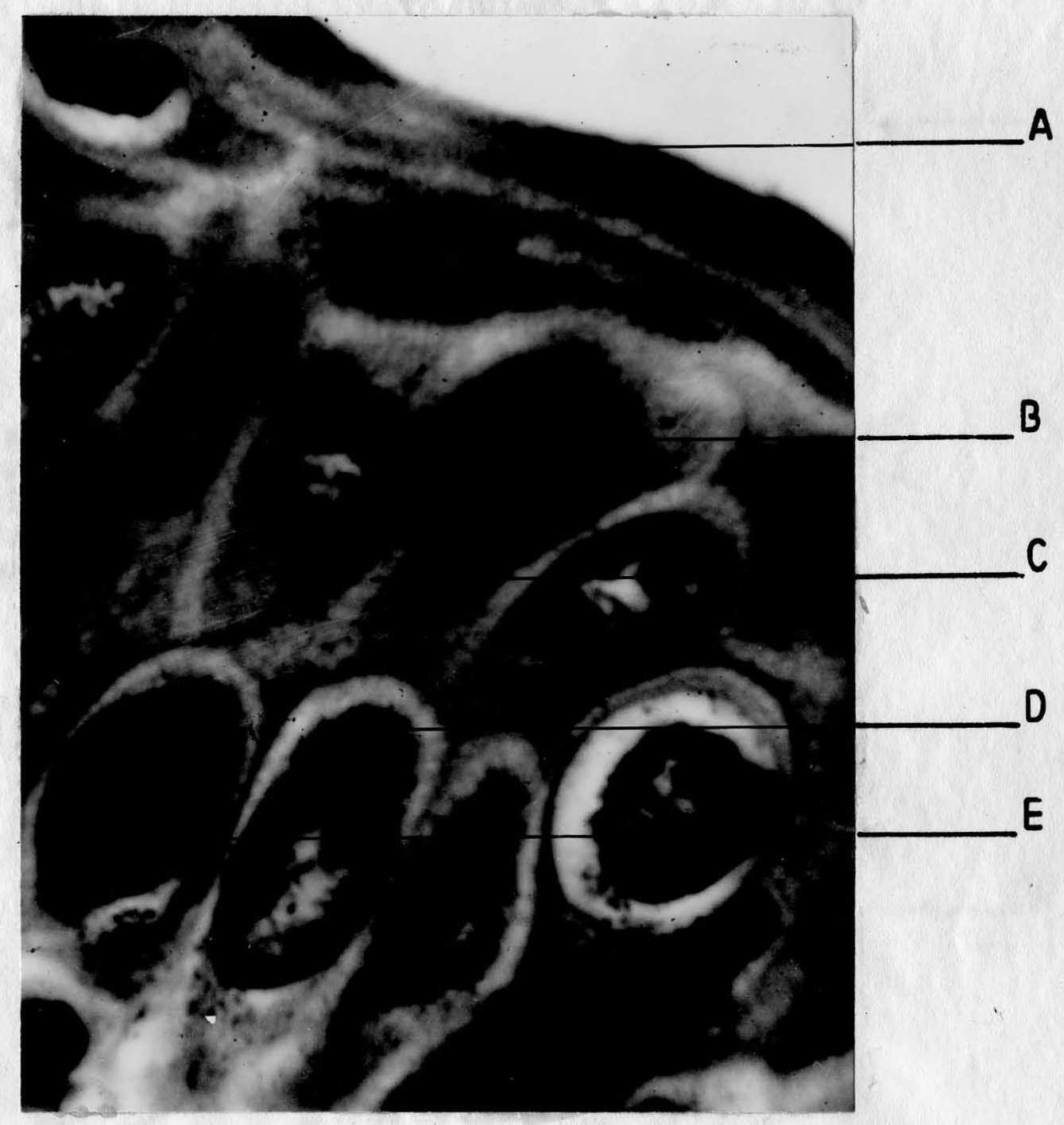

Figure 10 
PLATE IV

- Abbreviations:

A. - Stratum granulosum

B. - Fusiform nucleus of basal layer

Figure 11

thuman epidermis. Note fusiform nucleus of basal lover and flattened nuclei of stratum granulosum. liso Also observe flattened and angular cells of the spinosum of the stratum granulosum. $1900 \mathrm{x}$.

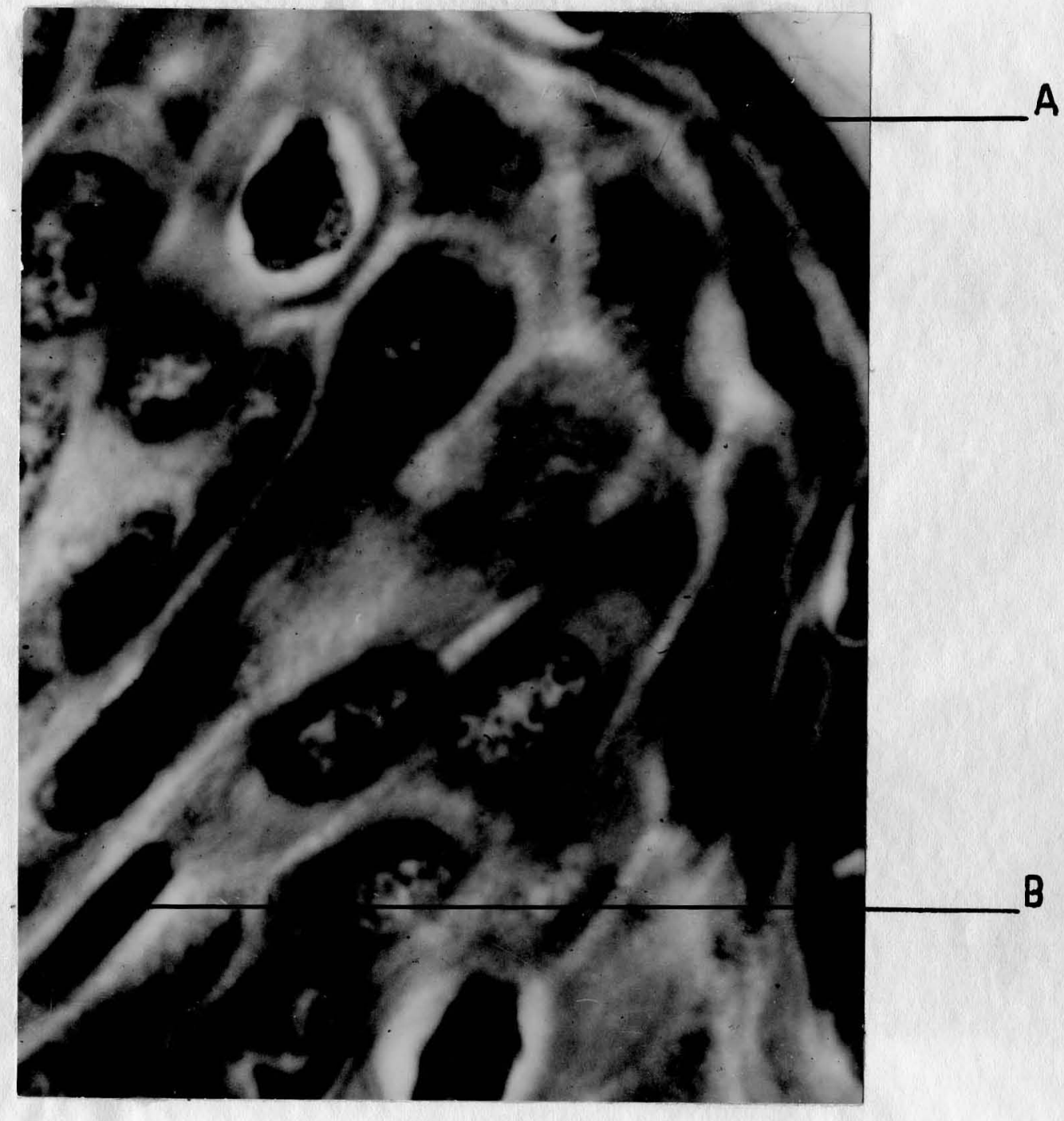

Figure 11 
PLATE V

Abbreviation:

A. - Cell in telophase stage of division B. - Diffuse pigment

Figure 12

Note telophase, in lower spinosum, with clear zo surrounding the muclei, presence of intercellular bridges at periphery of of intereellular bridges at pellis. Intereellular bridges have not yet appeared between the two daughter cells. Also note abundance of pigment. 1900x.

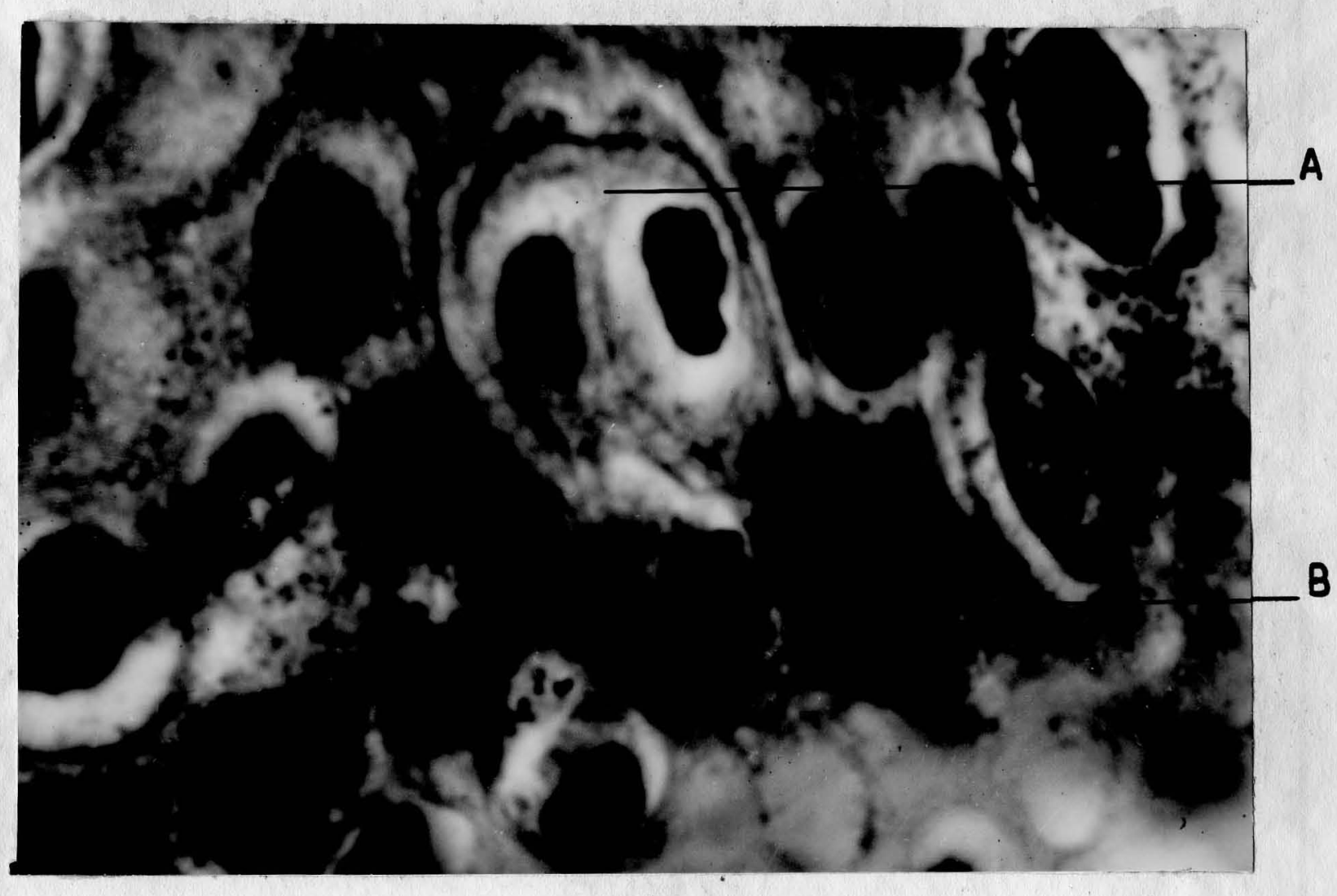

Figure 12 
PLATE VI

Figure 13

Human epidermis. Note anaphase in center of rigure located in middle of spinosum. Also note clear zone around melear material. $1900 x$.

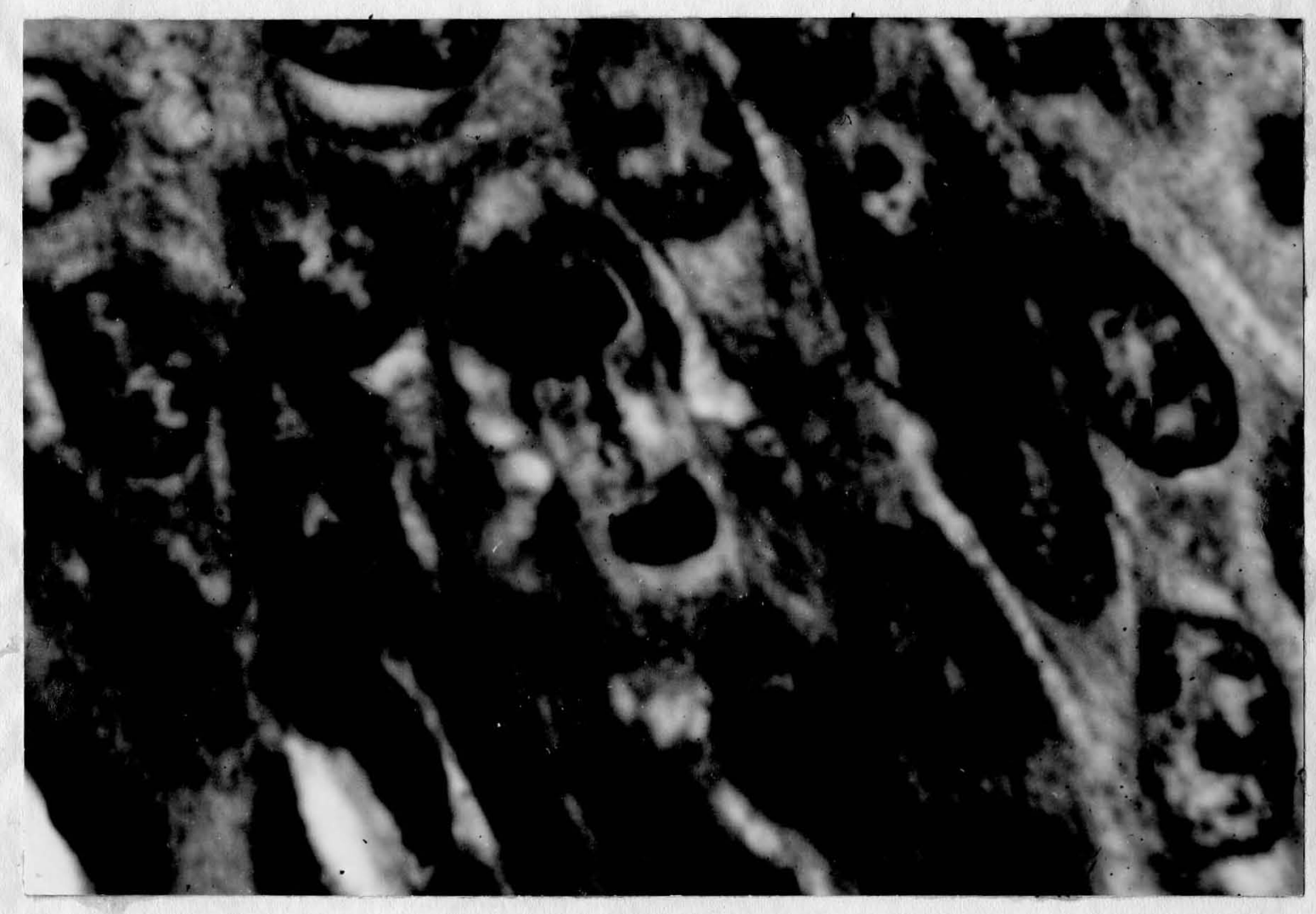

Figure 13 

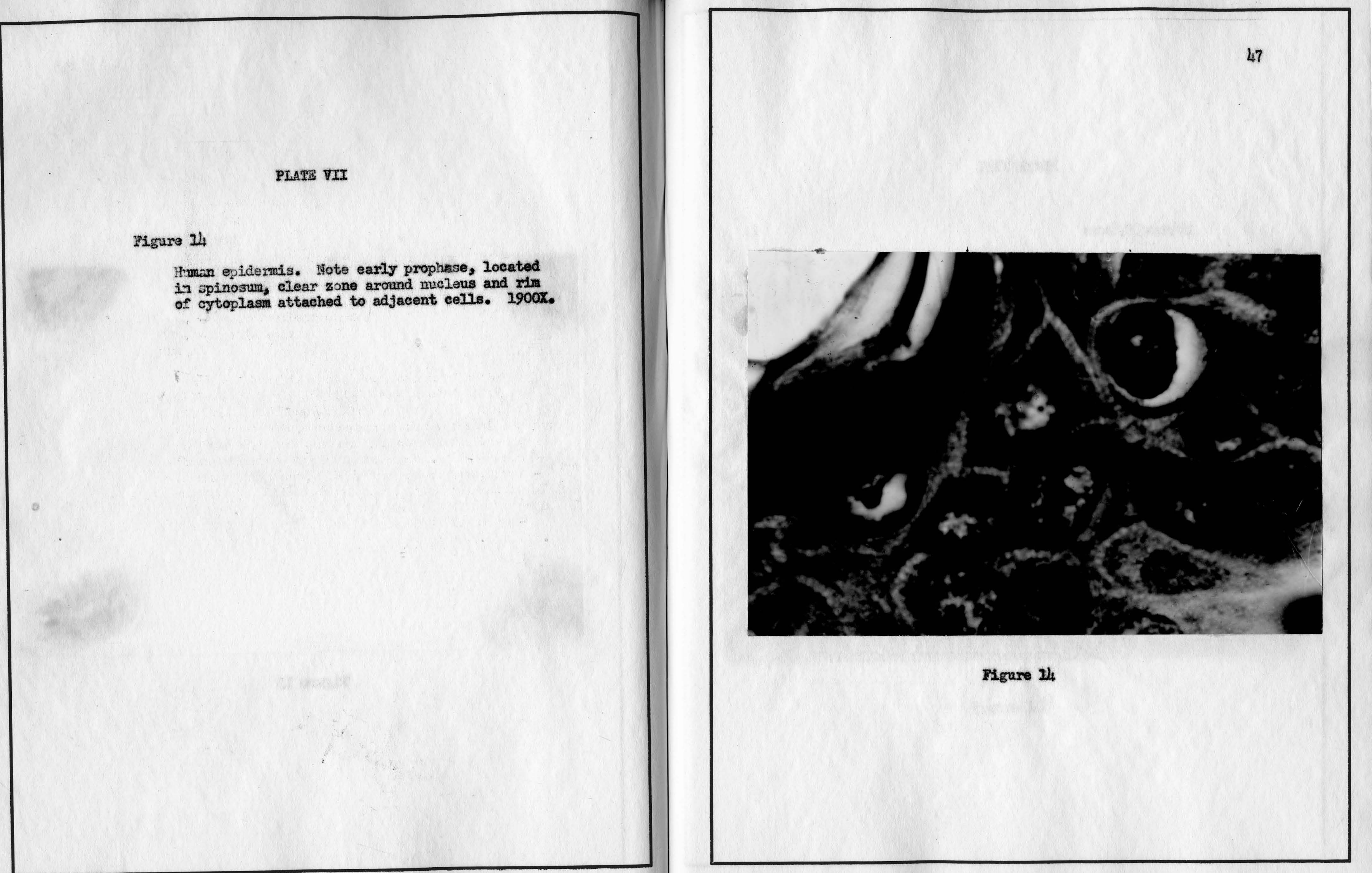
PLATE vIrx

Abbreviations:

$$
\text { A. - Typieal clear cell }
$$

\section{Figure 15}

Huwan epldersuis. Note very early clear cell with ring of cytoplasm connected to other ijo $1900 x$.

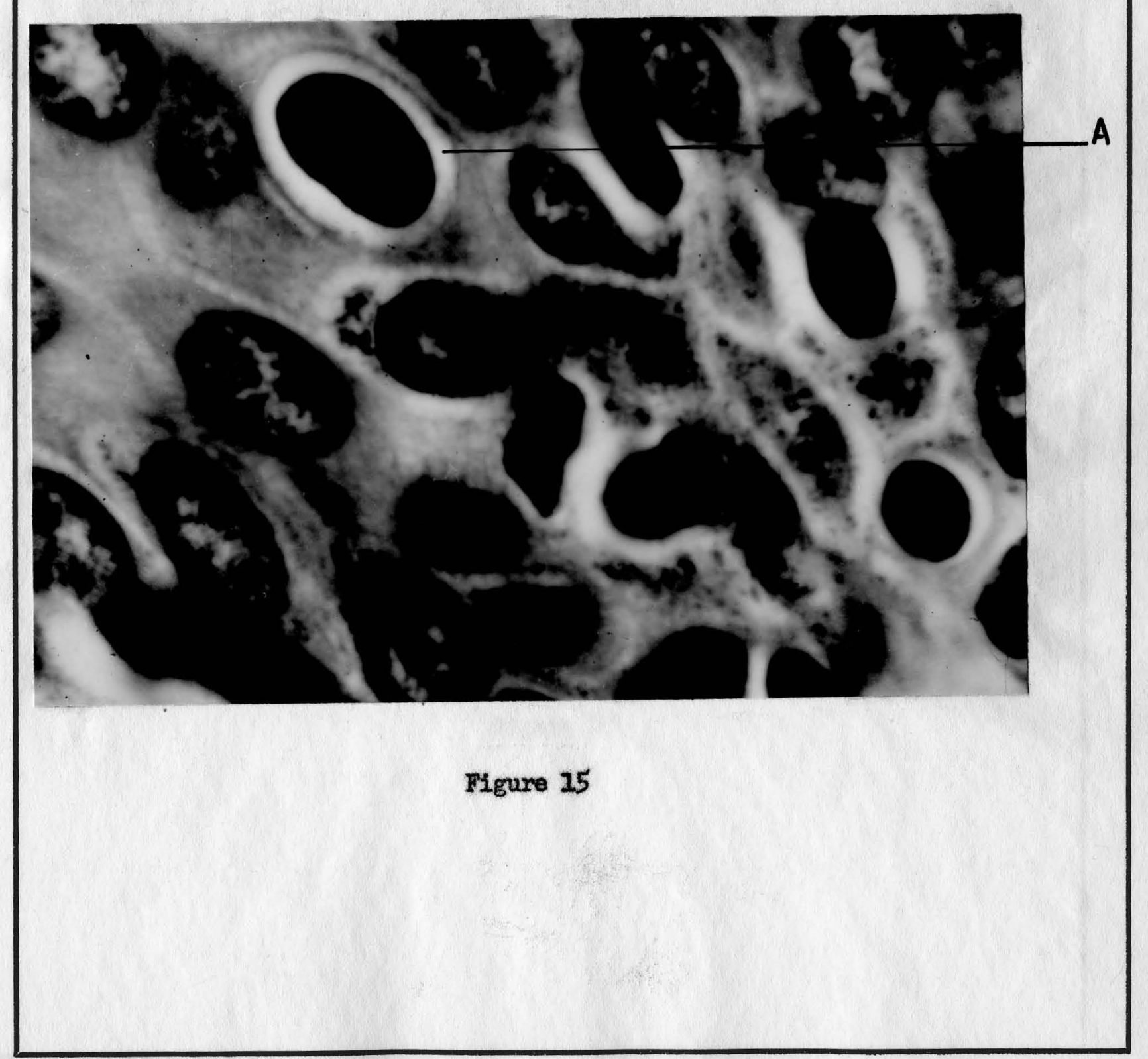


PLATE $\mathbf{x}$

Figure 16

Human epidermis, Note early prophase showing clear zone and intercellular

bridges in stratum spinosum. $1900 x$.

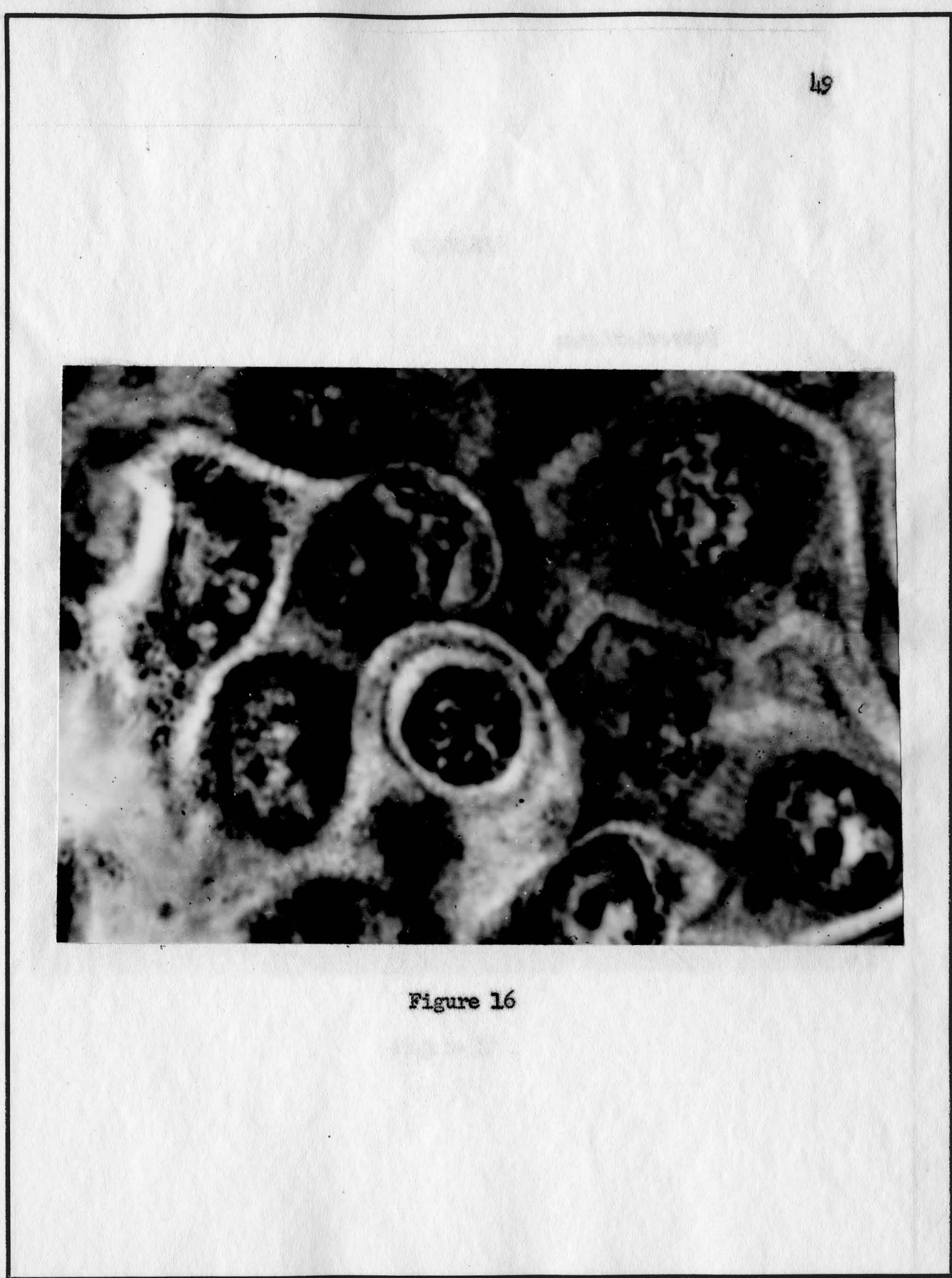


PLATE $X$

Abbreviations:

A. - Typical reconstruction cell B. - Typical early clear cell

Figure 17

Human apidermis. Note typical single early cell with rim of cytoplesm

comnected to cytoplasm of adjacent

cells by intercellular bridges. A7so

cells by intercellicar bridgen

note typical duplicate reconstruction

present. 1900\%.

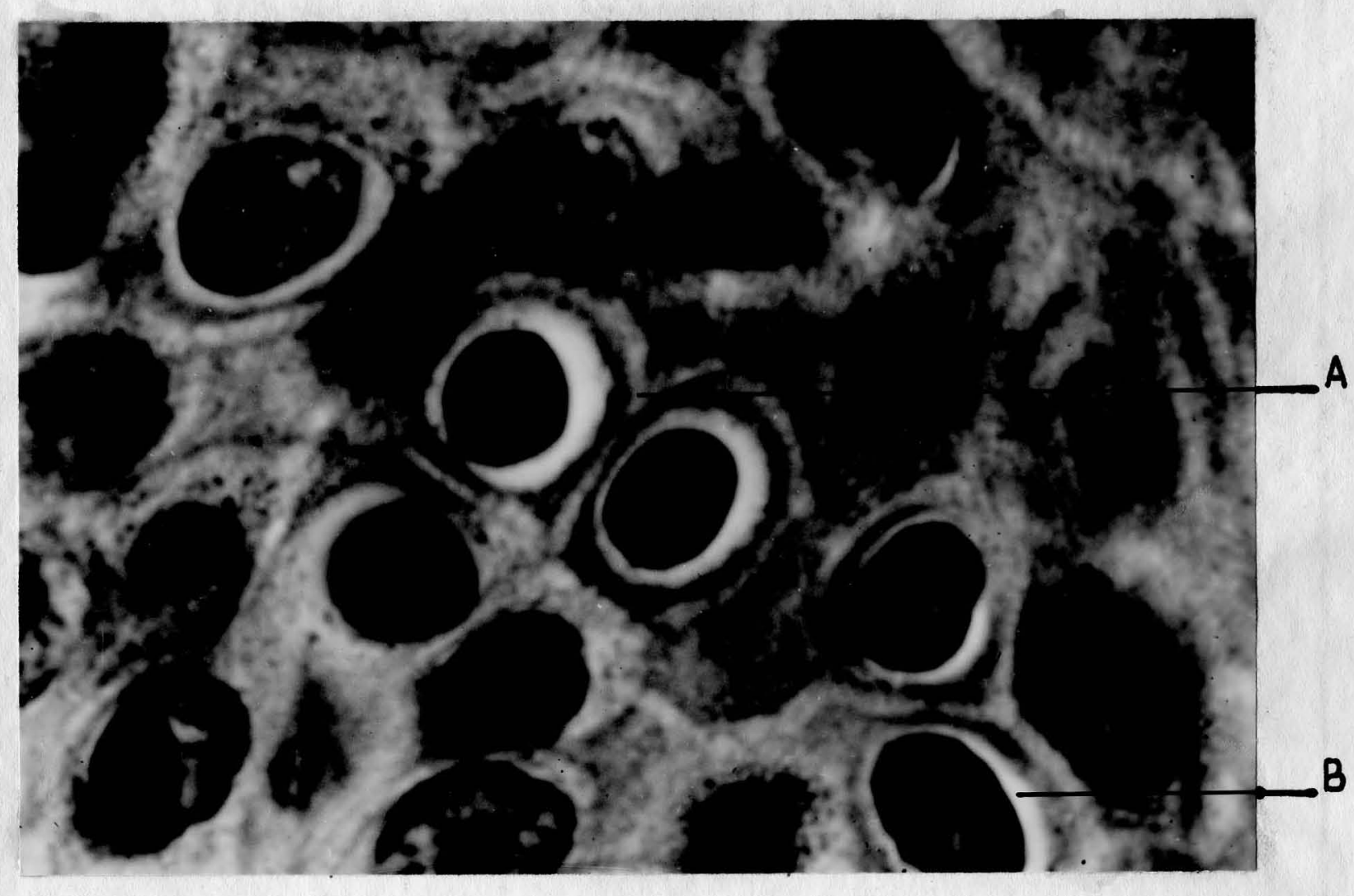

Figure 17 
PLATE XI

Figure 18

Epidernis. Amblystama larva. Note mitotic

Plgure (metaphase) with clear zone around

chromosomal mass. $450 \mathrm{x}$.

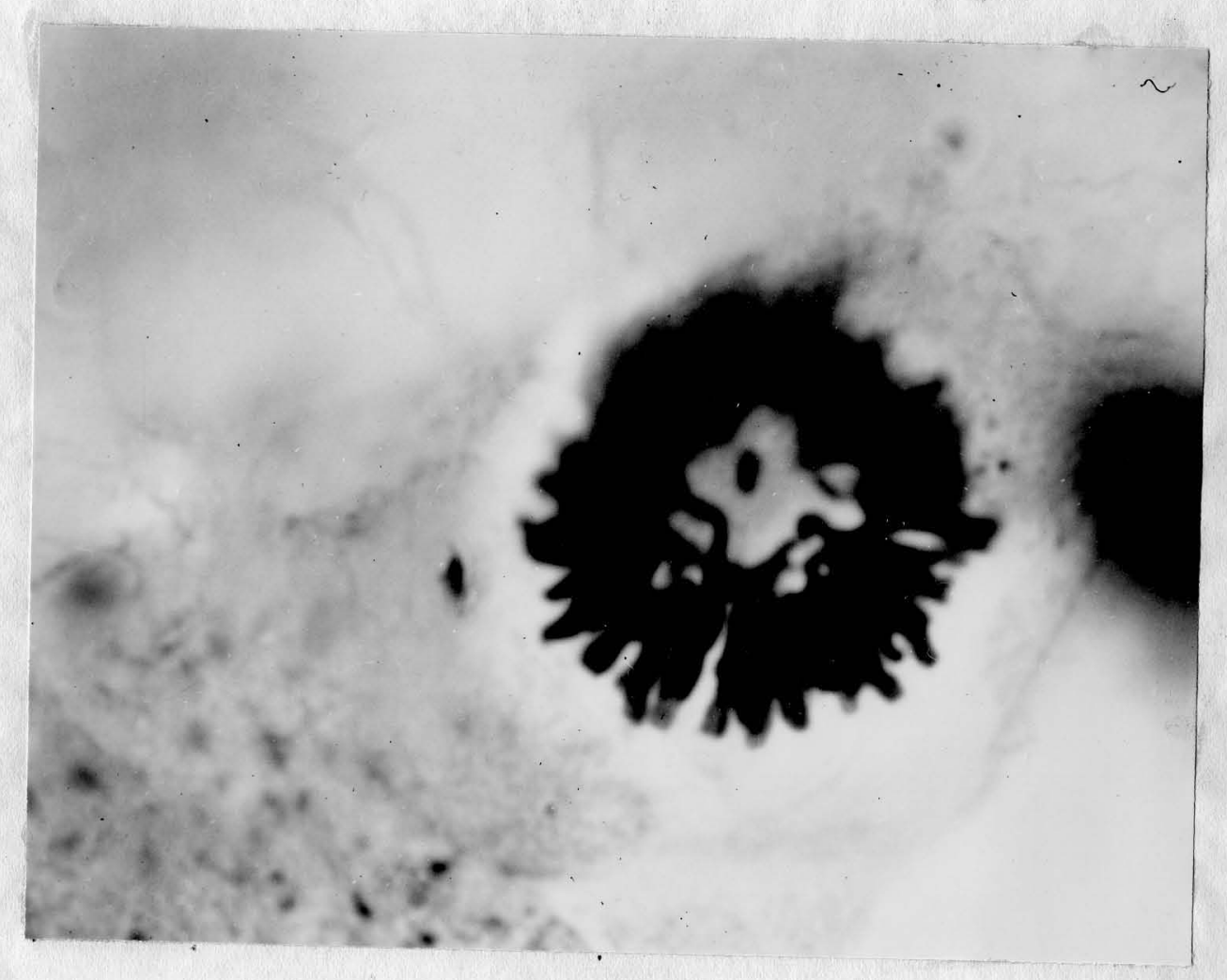

Figure 18 
STA T ISTICAIA P PENDIX 


\section{APPRRDI I}

STATISHCAT DATA FOR 8:00 A.H.

\begin{tabular}{|c|c|c|c|c|c|c|c|c|}
\hline \multicolumn{3}{|c|}{ GLEAR CELTS } & \multicolumn{3}{|c|}{ GHROMOSOKAL STAOES } & \multicolumn{3}{|c|}{ RECONSTRUCTION CELES } \\
\hline a & $(d-d)$ & $(a-d)^{2}$ & d & $(d-d)$ & $(a-a)^{2}$ & d & $(d-d)$ & $(a-d)^{2}$ \\
\hline 1.10 & 0.05 & .0125 & 0.54 & .59 & $.348 \mathrm{a}$ & $\mid 5.14$ & 1.55 & 2.4025 \\
\hline 1.27 & 0.22 & .0484 & 1.02 & .12 & .00144 & 2.13 & 1.46 & 2.1316 \\
\hline 1.94 & 0.89 & .7921 & 1.45 & .32 & .1024 & 2.74 & 0.85 & .7225 \\
\hline 0.81 & 0.24 & .0576 & 10.52 & .61 & .3722 & 4.83 & 1.24 & 1.5376 \\
\hline 0.76 & 0.29 & .0842 & 0.35 & .78 & .6084 & 2.25 & 1.34 & 1.7956 \\
\hline 2.57 & 1.52 & 2.3204 & 1.55 & .42 & .1764 & $\mid 7.59$ & 4.00 & 16,0000 \\
\hline 1.29 & 0.24 & .0576 & 0.47 & .66 & .4356 & 4.46 & .87 & .7569 \\
\hline 0.53 & 0.52 & .2704 & 1.02 & .21 & .012 & 2.91 & .68 & .4624 \\
\hline 0.67 & 0.38 & .1444 & 1.24 & .11 & .012 & 2.99 & .60 & .3600 \\
\hline 0.71 & 0.34 & .2156 & 2.59 & 1.46 & 2.1316 & 3.24 & .35 & .1225 \\
\hline \multicolumn{3}{|c|}{ Total $(d-d)^{2}-3.8931$} & \multicolumn{3}{|c|}{ Total $(d-\bar{d})^{2}-4.2132$} & \multicolumn{3}{|c|}{ Tota1 $(d-\bar{d})^{2}=26.2916$} \\
\hline \multicolumn{2}{|c|}{$\begin{array}{l}\text { Arithmetical } \\
\text { Hean }\end{array}$} & $=1.05$ & \multicolumn{2}{|c|}{$\begin{array}{l}\text { Artithnetical } \\
\text { Hean }\end{array}$} & $=1.13$ & \multicolumn{2}{|c|}{$\begin{array}{l}\text { Arithmetica } \\
\text { Lean }\end{array}$} & $=3.59$ \\
\hline \multicolumn{2}{|c|}{$\begin{array}{l}\text { Standard } \\
\text { doviation }\end{array}$} & $= \pm 0$ & \multicolumn{2}{|c|}{$\begin{array}{l}\text { Standard } \\
\text { deviation }\end{array}$} & $= \pm 0.22$ & \multicolumn{2}{|c|}{$\begin{array}{l}\text { Standerd } \\
\text { deviation }\end{array}$} & $= \pm 0.54$ \\
\hline
\end{tabular}


54

APPENDIX I

STATISTICAL DATA FOR 9:00 A.H.

\begin{tabular}{|c|c|c|c|c|c|c|c|c|}
\hline \multicolumn{3}{|c|}{ CLEAR CBLIS } & \multicolumn{3}{|c|}{ CHROMOSOHAT STAGES } & \multicolumn{3}{|c|}{ RECONSTHUCTION CETSS } \\
\hline d & $(a-a)$ & $\left(a-a^{2}\right)^{2}$ & d & $(d-d)$ & $(a-d)^{2}$ & d & $(a-d)$ & $(d-\bar{d})^{2}$ \\
\hline 1.14 & 0.29 & .0841 & 0.27 & 0.28 & .0784 & 2.78 & 0.02 & .0002 \\
\hline 1.74 & 0.31 & .0961 & 0.44 & 0.01 & .0001 & 2.42 & 0.37 & .1369 \\
\hline 1.82 & 0.39 & .152 & 0.146 & 0.03 & .0009 & 1.83 & 0.96 & .9216 \\
\hline 0.86 & 0.57 & .3249 & 0.29 & 0.16 & .0256 & 2.58 & 0.21 & .0442 \\
\hline 1.39 & 0.04 & .0016 & 0.29 & 0.26 & .0676 & 2.30 & 0.49 & .210 \\
\hline 1.90 & 0.47 & .2209 & 0.95 & 0.50 & .2500 & 1.12 & 1.67 & 2,7889 \\
\hline 0.55 & 0.88 & $.774 h$ & 0.17 & 0.28 & .0784 & 3.89 & 1.10 & 1.2100 \\
\hline 2.45 & 0.02 & .0004 & 0.83 & 0.38 & .24444 & 5.84 & 3.05 & 9.3025 \\
\hline 0.94 & 0.49 & $.24,01$ & 0.38 & 0.07 & .0049 & 2.27 & 0.52 & .2704 \\
\hline \multicolumn{3}{|c|}{ Totel $(d-\bar{d})^{2}=1.8946$} & \multicolumn{3}{|c|}{$\operatorname{Tota1}(\alpha-\bar{d})^{2}=.6503$} & \multicolumn{3}{|c|}{ Total $(d-d)^{2}=14.9146$} \\
\hline \multicolumn{2}{|c|}{$\begin{array}{l}\text { Arithmeticel } \\
\text { Hean }\end{array}$} & $=1.43$ & \multicolumn{2}{|c|}{$\begin{array}{l}\text { Arithmetical } \\
\text { Mean }\end{array}$} & $=0.45$ & \multicolumn{2}{|c|}{$\begin{array}{l}\text { Arlthretical } \\
\text { Hean }\end{array}$} & $=2.79$ \\
\hline \multicolumn{2}{|c|}{$\begin{array}{l}\text { Standard } \\
\text { deviation }\end{array}$} & $= \pm 0.24$ & \multicolumn{2}{|c|}{$\begin{array}{l}\text { Standard } \\
\text { deviation }\end{array}$} & $= \pm 0.08$ & \multicolumn{2}{|c|}{$\begin{array}{l}\text { Standard } \\
\text { derlatian }\end{array}$} & $= \pm 0.40$ \\
\hline
\end{tabular}


APPENDTI I

STATISTTCAL DATA FOR 10,00 A.K.

\begin{tabular}{|c|c|c|c|c|c|c|c|c|}
\hline \multicolumn{3}{|c|}{ CIBAR CELTS } & \multicolumn{3}{|c|}{ CHROMOSOMAL STAGES } & \multicolumn{3}{|c|}{ PREONSTHWTTOU CBLLS } \\
\hline d & $(a-d)$ & $(d-d)^{2}$ & d & $(d-\bar{d})$ & $(d-\bar{d})^{2}$ & d & $(d-d)$ & $(a-a)^{2}$ \\
\hline 0.32 & 0.33 & .1089 & 0.24 & 0.38 & .1444 & 0.80 & 0.21 & .0442 \\
\hline 0.66 & 0.01 & .0001 & 0.44 & 0.18 & .0324 & 1,00 & 0.02 & .0001 \\
\hline 1.08 & 0.43 & .2849 & 0.58 & 0.04 & .0026 & 0.65 & 0.36 & .1296 \\
\hline 0.69 & 0.04 & .0016 & 0.62 & 0.0 & 0.0 & 2.84 & 0.83 & .6889 \\
\hline 1.02 & 0.36 & .1296 & 0.60 & 0.02 & .0004 & 0.47 & 0.54 & .2916 \\
\hline 0.78 & 0.13 & .0169 & 0.37 & 0.25 & .0625 & 1.30 & 0.29 & .0842 \\
\hline 0.83 & 0.18 & .0324 & 0.28 & 0.34 & .1256 & 0.65 & 0.36 & .1296 \\
\hline 0.65 & 0.0 & 0.0 & 0.39 & 0.23 & .0529 & 1.39 & 0.38 & .2444 \\
\hline 0.37 & 0.28 & .0784 & 0.09 & 0.53 & .2809 & 1.04 & 0.03 & .0009 \\
\hline 0.42 & 0.23 & .0529 & 0.23 & 0.39 & .152 & 0.73 & 0.28 & .0784 \\
\hline 0.57 & 0.00 & .0064 & 2.01 & 1.39 & 1.9321 & 1.15 & 0.14 & .0196 \\
\hline \multicolumn{3}{|c|}{ Total $(d-d)^{2}=.6122$} & \multicolumn{3}{|c|}{ Totel $(d-\bar{d})^{2}=2.7769$} & \multicolumn{3}{|c|}{ rotal $(d-d)^{2}=3.6113$} \\
\hline \multicolumn{2}{|c|}{$\begin{array}{l}\text { Axithmetteal } \\
\text { Lean }\end{array}$} & $=0.65$ & \multicolumn{2}{|c|}{$\begin{array}{l}\text { Arithmotioal } \\
\text { Lean }\end{array}$} & $=0.62$ & \multicolumn{2}{|c|}{$\begin{array}{l}\text { Art thmetical } \\
\text { Lean }\end{array}$} & -1.0 \\
\hline \multicolumn{2}{|c|}{$\begin{array}{l}\text { Standerd } \\
\text { doviation }\end{array}$} & - \pm 0.07 & \multicolumn{2}{|c|}{$\begin{array}{l}\text { Standard } \\
\text { derlation }\end{array}$} & $= \pm 0,1$ & \multicolumn{2}{|c|}{$\begin{array}{l}\text { Standard } \\
\text { deviation }\end{array}$} & $= \pm 0.0$ \\
\hline
\end{tabular}


APPEADIX I

STATISTICAI DATA FOR 11:00 1.M.

\begin{tabular}{|c|c|c|c|c|c|c|c|c|}
\hline \multicolumn{3}{|c|}{ OLFAR CETIS } & \multicolumn{3}{|c|}{ GHROMOSOMAL STACES } & \multicolumn{3}{|c|}{ RECONSTBUCTIOA CELIS } \\
\hline $\mathbf{d}$ & $(d-d)$ & $(a-d)^{2}$ & d & $(a-d)$ & $(a-a)^{2}$ & $\mathbf{a}$ & $(d-d)$ & $(a-a)^{2}$ \\
\hline 0.62 & 0.01 & $.000 \mathbf{2}$ & 0.0 & 0.26 & .0001 & 1.56 & 0.90 & .8100 \\
\hline 0.38 & 0.23 & .0529 & 0.18 & 0.08 & .0064 & 0.49 & 0.17 & .0289 \\
\hline 0.87 & 0.26 & .0676 & 0.42 & 0.26 & .0256 & 1.52 & 0.86 & .7396 \\
\hline 0.94 & 0.33 & .1089 & 0.25 & 0.01 & .0002 & 0.87 & 0.21 & .0442 \\
\hline 0.56 & 0.05 & .0025 & 0.34 & 0.08 & .0064 & 1.00 & 0.34 & .1156 \\
\hline 0.90 & 0.31 & .0961 & 0.38 & 0.12 & .0144 & 0.54 & 0.12 & .0144 \\
\hline 0.72 & 0.10 & .0100 & 0.28 & 0.02 & .0004 & 0.59 & 0.07 & .0049 \\
\hline 0.27 & 0.34 & .1756 & 0.15 & 0.11 & .0121 & 0.01 & 0.65 & .4225 \\
\hline 0.40 & 0.21 & .0447 & 0.29 & 0.03 & .0009 & 0.40 & 0.26 & .0676 \\
\hline 0.66 & 0.05 & .0025 & 0.19 & 0.07 & .0049 & 0.27 & 0.39 & .1521 \\
\hline 0.65 & 0.04 & .0016 & 0.09 & 0.17 & .0289 & 0.37 & 0.29 & .0842 \\
\hline \multicolumn{3}{|c|}{ Total $(d-d)^{2}=.5019$} & \multicolumn{3}{|c|}{ Total $(d-\bar{d})^{2}=.1677$} & \multicolumn{3}{|c|}{ Total $(d-d)^{2}=2.4838$} \\
\hline \multicolumn{2}{|c|}{$\begin{array}{l}\text { Arl thwetscal } \\
\text { Neen }\end{array}$} & $=0.61$ & \multicolumn{2}{|c|}{$\begin{array}{l}\text { Arf thretileal } \\
\text { Kean }\end{array}$} & $=0.26$ & \multicolumn{2}{|c|}{$\begin{array}{l}\text { Arlthmetical } \\
\text { Hean }\end{array}$} & $=0.66$ \\
\hline \multicolumn{2}{|c|}{$\begin{array}{l}\text { Standard } \\
\text { devlation }\end{array}$} & $= \pm 0.07$ & \multicolumn{2}{|c|}{$\begin{array}{l}\text { Standard } \\
\text { deviation }\end{array}$} & $= \pm 0$ & \multicolumn{2}{|c|}{$\begin{array}{l}\text { Standard } \\
\text { deriation }\end{array}$} & $= \pm 0.15$ \\
\hline
\end{tabular}




\section{APPEMDIX I}

STATISTICAL DATA FOR 12:00 Hoon

\begin{tabular}{|c|c|c|c|c|c|c|c|c|}
\hline \multicolumn{3}{|c|}{ CLEAR CELTS } & \multicolumn{3}{|c|}{ CEROMOSOYAT STAGES } & \multicolumn{3}{|c|}{ PECONSTRUCTIOU CEILS } \\
\hline d & $(d-d)$ & $(d-\bar{d})^{2}$ & d & $(d-d)$ & $(d-\bar{d})^{2}$ & d & $(d-d)$ & $(d-d)^{2}$ \\
\hline 1.17 & .02 & .0004 & 1.84 & .92 & .8464 & 2.06 & .80 & .6400 \\
\hline .97 & .22 & .0484 & 1.54 & .62 & .3844 & 1.13 & .13 & .0169 \\
\hline .72 & .47 & .2209 & 2.28 & .36 & .1296 & 1.99 & .73 & .5329 \\
\hline .79 & .40 & .1600 & 1.36 & .34 & .1156 & 1.24 & .02 & .0004 \\
\hline 2.62 & .43 & .1849 & 1.31 & .39 & .1522 & .24 & 1.02 & 1.0404 \\
\hline 1.61 & .42 & .1764 & .58 & .34 & .1156 & 1.01 & .25 & .0625 \\
\hline 1.61 & .42 & .1764 & .23 & .69 & .4761 & 1.49 & .23 & .0529 \\
\hline 1.53 & .34 & .2156 & .20 & .72 & .5184 & .37 & .89 & .7921 \\
\hline 1.37 & .18 & .0324 & .95 & .03 & .0009 & 1.47 & .21 & .0447 \\
\hline 1.00 & .19 & .0361 & .40 & .52 & .2704 & 1.14 & .12 & .0244 \\
\hline 1.72 & .53 & .2809 & 1.06 & .14 & .0196 & 1.13 & .13 & .0169 \\
\hline 1.06 & .13 & .0169 & .57 & .35 & .1225 & .78 & .48 & .2304 \\
\hline .31 & .88 & .7744 & .52 & .40 & .1600 & .62 & .64 & .4096 \\
\hline \multicolumn{3}{|c|}{ Total $(d-d)^{2}=2.22$} & \multicolumn{3}{|c|}{ Total $(d-\bar{d})^{2}=3.3216$} & \multicolumn{3}{|c|}{ Total $(\mathrm{d}-\mathrm{d})^{2}-3.8535$} \\
\hline \multicolumn{2}{|c|}{$\begin{array}{l}\text { Arithmetical } \\
\text { Hean }\end{array}$} & $=1.19$ & \multicolumn{2}{|c|}{$\begin{array}{l}\text { Arl thmetical } \\
\text { Hoan }\end{array}$} & -.92 & \multicolumn{2}{|c|}{$\begin{array}{l}\text { ArIthmetioa } \\
\text { Hean }\end{array}$} & -1.26 \\
\hline \multicolumn{2}{|c|}{$\begin{array}{l}\text { Standard } \\
\text { derlation }\end{array}$} & $= \pm 0.11$ & \multicolumn{2}{|c|}{$\begin{array}{l}\text { Standard } \\
\text { deriation }\end{array}$} & $= \pm 0.15$ & \multicolumn{2}{|c|}{$\begin{array}{l}\text { Standard } \\
\text { derlation }\end{array}$} & $= \pm 0.16$ \\
\hline
\end{tabular}


APPEMDIX I

STATISTICAI, DATA POR 1,00 P.M.

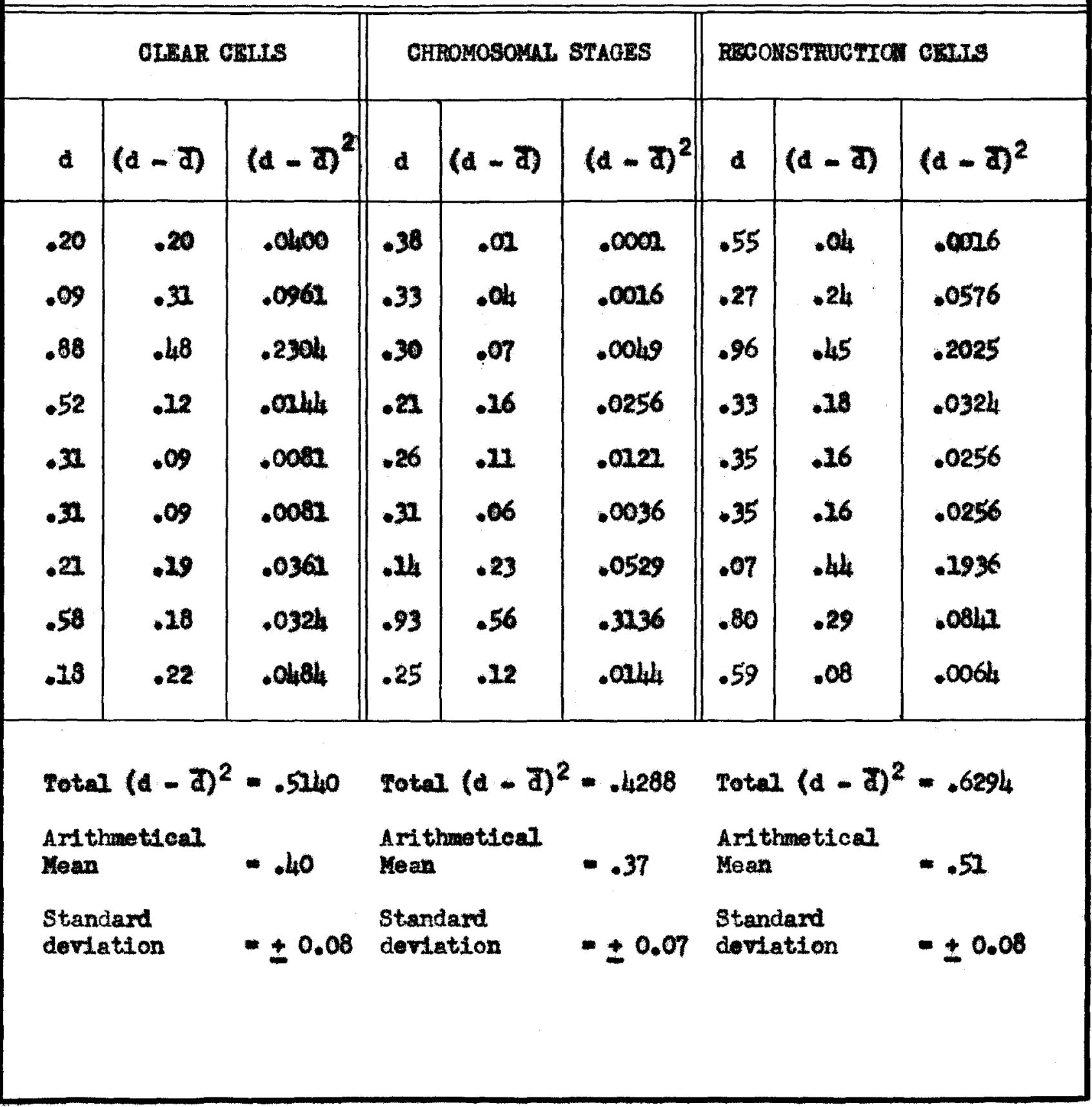


APPMIDIX I

STATISTTCAI DATA FOR 2:00 P.K.

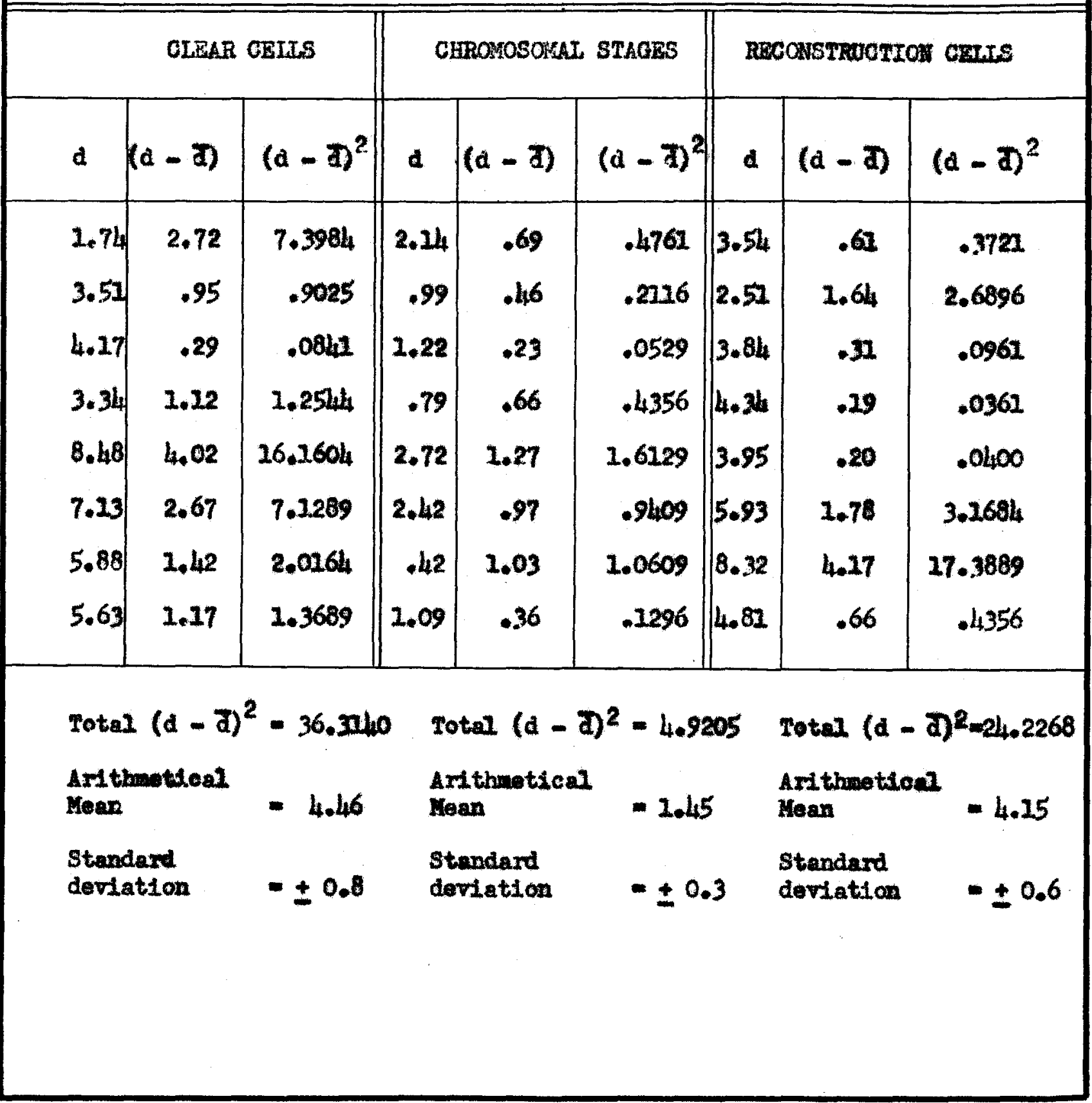




\section{APPBDDX I}

STATISTICAT DATA FOR 3:00 P.M.

\begin{tabular}{|c|c|c|c|c|c|c|c|c|}
\hline \multicolumn{3}{|c|}{ CLBAR CIBTS } & \multicolumn{3}{|c|}{ CHROMOSOMAT SRACRS } & \multicolumn{3}{|c|}{ RECONSTHUCTIO OAtrs } \\
\hline a & $(d-d)$ & $(d-z)^{2}$ & a & $(a-d)$ & $(a-a)^{2}$ & d & $(d-\bar{d})$ & $(d-a)^{2}$ \\
\hline 2.46 & •?:6 & .0676 & 1.30 & .40 & .1600 & 3.84 & .4 .3 & .28149 \\
\hline 2.34 &.$u_{4}$ & .926 & 87 & .63 & .3969 & 5.73 & 1.46 & 2.7849 \\
\hline 1.03 & 1.77 & 1.3689 & 1.98 & .38 & 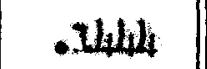 & 2.84 & 1.143 & 2.0449 \\
\hline 2.70 & .50 & .9500 & 2.52 & 1.02 & 1. nlak & 7.57 & 3.30 & 10.8900 \\
\hline 1.59 & .61. & .3722 & 1.32 & .18 & .0324 & 2.81 & $1.1,6$ & 2.1316 \\
\hline 4.06 & 1.86 & 3.1596 & 1.79 & .29 & .0841 & 4.9 & .26 & .0676 \\
\hline .42 & 1.78 & 3.2684 & .2 & 1.29 & 1.6643 & .85 & 3.12 & 11.6964 \\
\hline \multicolumn{3}{|c|}{ Total $(\alpha-d)^{2}=8.7062$} & \multicolumn{3}{|c|}{ Total $(d-d)^{2}=3.5223$} & \multicolumn{3}{|c|}{ Total $(\mathrm{d}-\mathrm{d})^{2}-29.1470$} \\
\hline \multicolumn{2}{|c|}{$\begin{array}{l}\text { Art throticed } \\
\text { Hean }\end{array}$} & $=2.20$ & \multicolumn{2}{|c|}{$\begin{array}{l}\text { Art thmetion } \\
\text { Hean }\end{array}$} & $=1.50$ & \multicolumn{2}{|c|}{$\begin{array}{l}\text { Ard thmetical } \\
\text { Yean }\end{array}$} & $=4.27$ \\
\hline \multicolumn{2}{|c|}{$\begin{array}{l}\text { Stendard } \\
\text { deviation }\end{array}$} & $= \pm 0.45$ & \multicolumn{2}{|c|}{$\begin{array}{l}\text { Standard } \\
\text { deviation }\end{array}$} & $= \pm 0.29$ & \multicolumn{2}{|c|}{$\begin{array}{l}\text { Standard } \\
\text { deviation }\end{array}$} & $- \pm 0,45$ \\
\hline
\end{tabular}


APPEHDI I

STAPISTIOAI DATA FOR L.00 P.H.

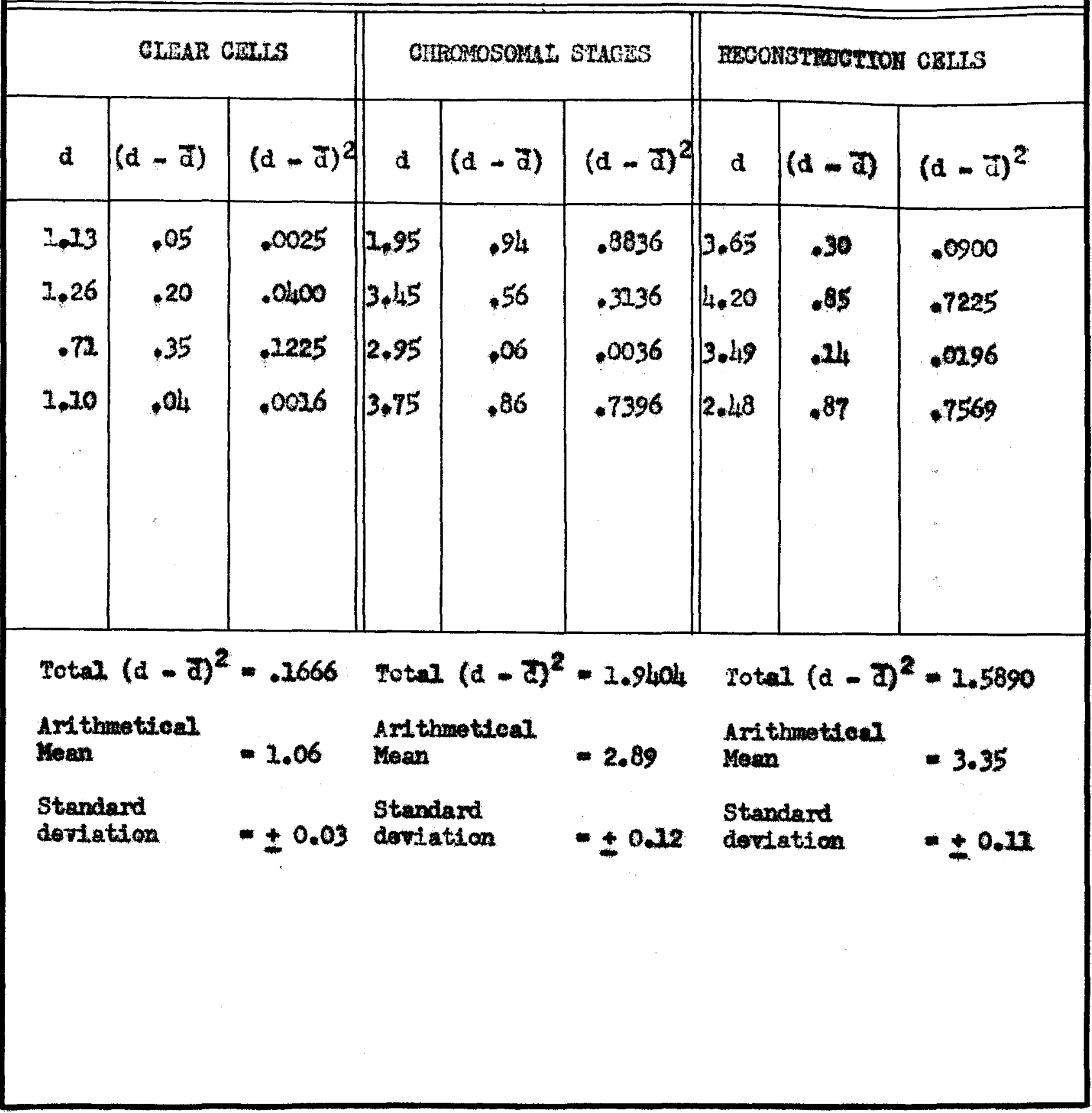


APPEDT I

STATISTTOAL DATA FOR 5:00 P.X.

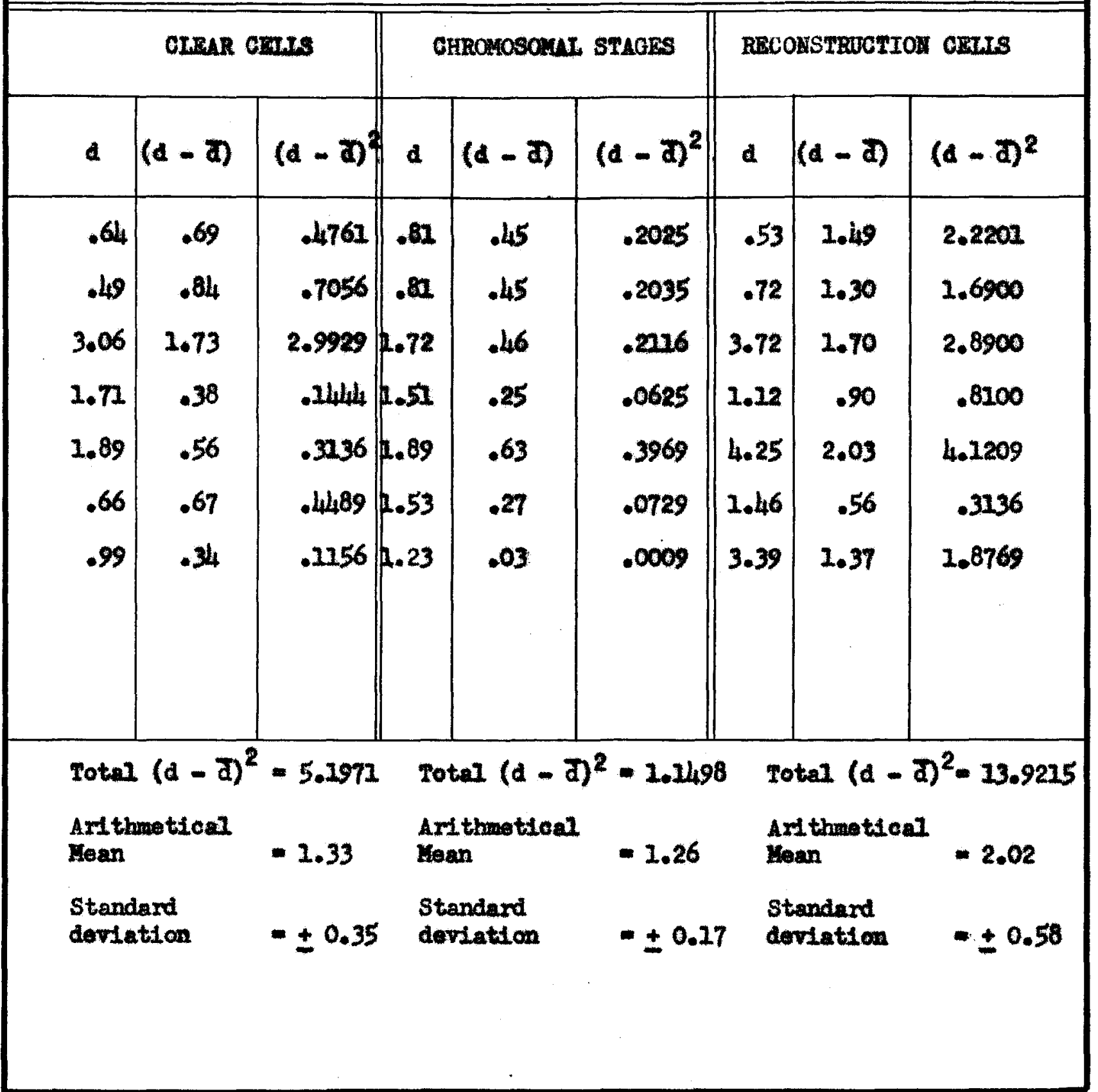




\section{3}

APPRIDI I

STATISTICAL DATA FOR 6,00 P.X.

\begin{tabular}{|c|c|c|c|c|c|c|c|c|}
\hline \multicolumn{3}{|c|}{ Gumen cxis } & \multicolumn{3}{|c|}{ chromosoun stuass } & \multicolumn{3}{|c|}{ 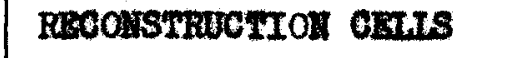 } \\
\hline a & $(a-d)$ & $\left(a-a^{2}\right.$ & $\mathbf{d}$ & $(d-d)$ & $(a-d)^{2}$ & d & $(d-d)$ & $(a-a)^{2}$ \\
\hline 1.62 & .27 & .0729 & 1.13 & .43 & .1840 & 2.72 & .30 & .0900 \\
\hline 1.54 & .29 & .0361 & .05 & .25 & .0225 & 3.63 & 1.22 & 1.4884 \\
\hline .82 & .53 & .2809 & .23 & .47 & .2209 & 2.92 & .51 & .2601 \\
\hline 1.62 & .27 & .0729 & .50 & .20 & .0400 & 2.41 & 0.0 & 0.0 \\
\hline 1.30 & .05 & .0025 & .32 & .38 & .24444 & 1.13 & 2.28 & 1.6384 \\
\hline .29 & 1.06 & 1.1236 & .33 & .37 & .1369 & 1.72 & .70 & .4900 \\
\hline 2.4 .45 & .20 & .0100 & .34 & .36 & .1296 & 1.46 & .95 & .9025 \\
\hline 2.11 & .76 & .5776 & 1.20 & .50 & .2500 & 3.75 & 1.34 & 1.7956 \\
\hline 1.84 & .49 & .2401 & .89 & .29 & .0361 & 3.68 & 1.27 & 1.6129 \\
\hline .91 & .44 & .1936 & .20 & .50 & .2500 & .44 & 2.47 & 2.1609 \\
\hline 1. 44 & .09 & .0081 & .21 & .49 & .2401 & 1.53 & .88 & .7744 \\
\hline \multicolumn{3}{|c|}{ Total $(d-d)^{2}-2.6183$} & \multicolumn{3}{|c|}{ Total $(d-d)^{2}=1.6554$} & \multicolumn{3}{|c|}{ Total $(\alpha-\pi)^{2}=11.2132$} \\
\hline \multicolumn{2}{|c|}{$\begin{array}{l}\text { Arithmotical } \\
\text { Hoan }\end{array}$} & $=1.35$ & \multicolumn{2}{|c|}{$\begin{array}{l}\text { Arithmetical } \\
\operatorname{Man}\end{array}$} & $=.70$ & \multicolumn{2}{|c|}{$\begin{array}{l}\text { Ar1 thmeticel } \\
\text { Kean }\end{array}$} & $=2.41$ \\
\hline \multicolumn{2}{|c|}{$\begin{array}{l}\text { Standard } \\
\text { devlation }\end{array}$} & $= \pm 0.15$ & \multicolumn{2}{|c|}{$\begin{array}{l}\text { Standard } \\
\text { deviation }\end{array}$} & $= \pm 0.12$ & \multicolumn{2}{|c|}{$\begin{array}{l}\text { Standard } \\
\text { deviation }\end{array}$} & $= \pm 0.32$ \\
\hline
\end{tabular}


APPIDIXI I

STAPISrBad DATA Fon 7,00 R.H.

\begin{tabular}{|c|c|c|c|c|c|c|c|c|}
\hline \multicolumn{3}{|c|}{ GEAR CDLIS } & \multicolumn{3}{|c|}{ chromosaut stuars } & \multicolumn{3}{|c|}{ HeOASTRUCTIOA CELIS } \\
\hline a & $(a-a)$ & $(\mathbf{a}-\mathbf{d})$ & d & $(a-d)$ & $(a-d)^{2}$ & a & $(d-a)$ & $(a-a)^{2}$ \\
\hline 1.27 & .38 & .2444 & .25 & .75 & .5625 & 3.06 & .23 & .0529 \\
\hline 1.68 & .03 & .0009 & .6 & .39 & .1521 & 2.22 & 1.07 & 1.11149 \\
\hline 1.44 & .21 & .0441 & .81 & .19 & .0361 & 5.13 & 2.84 & 3.3856 \\
\hline 1.38 & .27 & .0729 & 2.18 & 1.20 & 1.3924 & 5.62 & 2.32 & 5.3624 \\
\hline 1.69 & .04 & .0016 & .84 & .16 & .0256 & 2.64 & 1.65 & 2.7225 \\
\hline 2.21 & .54 & .2916 & .56 & . Wh & .2936 & $4 \cdot 34$ & 1.05 & 1.1025 \\
\hline 3.12 & 1.67 & 2.7889 & .10 & .90 & .8100 & 3.9 & .28 & .0784 \\
\hline 1.78 & .13 & .0068 & 2.24 & 1.14 & 1.2996 & 2.14 & 2.15 & 1.3225 \\
\hline 1.61 & .04 & .0026 & 1.06 & .06 & .0036 & 5.15 & 1.86 & 3.4596 \\
\hline .83 & .82 & .6724 & 2.67 & .67 & .4489 & 1.83 & 2.46 & 2.1326 \\
\hline \multicolumn{3}{|c|}{$\operatorname{Tota1}(d-d)^{2}=4.0353$} & \multicolumn{3}{|c|}{ Total $(d-d)^{2}=4.9244$} & \multicolumn{3}{|c|}{ Total $(d-d)^{2}=20.7829$} \\
\hline \multicolumn{2}{|c|}{$\begin{array}{l}\text { Art thmetieal } \\
\text { Hoan }\end{array}$} & $=1.65$ & \multicolumn{2}{|c|}{$\begin{array}{l}\text { Arithwetical } \\
\text { Nean }\end{array}$} & $-2,000$ & \multicolumn{2}{|c|}{ Arithwetieal } & -3.29 \\
\hline \multicolumn{2}{|c|}{$\begin{array}{l}\text { Standard } \\
\text { deviation }\end{array}$} & $= \pm 0.2$ & \multicolumn{2}{|c|}{$\begin{array}{l}\text { Standard } \\
\text { dertiatien }\end{array}$} & & \multicolumn{2}{|c|}{$\begin{array}{l}\text { Standard } \\
\text { derlation }\end{array}$} & $= \pm 0.4 \mathrm{a}$ \\
\hline
\end{tabular}




\section{IPPEADIX I}

STATrSTrouL BAZA FOR 8,00 P.X.

\begin{tabular}{|c|c|c|c|c|c|c|c|c|}
\hline \multicolumn{3}{|c|}{ CLRAF CRHIS } & \multicolumn{3}{|c|}{ 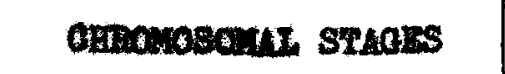 } & \multicolumn{3}{|c|}{ RECOASTRUETION CELS } \\
\hline d & $(d-d)$ & $\left(a-a^{2}\right)$ & a & $(a-2)$ & $(a-d)^{2}$ & d & $(a-d)$ & $(a-a)^{2}$ \\
\hline 1.79 & .52 & .2704 & 2 aln 6 & -32 & .7024 & 1.26 & .59 & .3482 \\
\hline .71 & .56 & .3136 & 1.20 & .06 & .0036 & 2.11 & .26 & .0676 \\
\hline 1.01 & .26 & .0676 & .52 & .63 & .3969 & 1.33 & .52 & .2704 \\
\hline 1.35 & .80 & .61000 & .93 & $.2 a$ & .0442 & 1.60 & .25 & .0625 \\
\hline .84 & .43 & .1849 & 1.16 & .02 & .0004 & .69 & 1.26 & 2.3456 \\
\hline 2.06 & .22 & .0442 & 1.09 & .05 & .0025 & 3.72 & 1.87 & 3.4969 \\
\hline 1.36 & .09 & .0082 & $20 \%$ & .97 & .0040 & 2.66 & .81 & .6561 \\
\hline 1.20 & .07 & .0049 & 89 & .25 & .0625 & 2.07 & .78 & .6084 \\
\hline 2.55 & 1.28 & $1.638 \mathrm{k}$ & 1.56 & .42 & .1764 & 4.78 & 2.93 & 8.5849 \\
\hline 1.09 & .18 & .0324 & 2.25 & .02 & .0001 & 3.23 & 1.38 & 1.9044 \\
\hline \multicolumn{3}{|c|}{ Total $(a-d)^{2}-3.2044$} & \multicolumn{3}{|c|}{$\operatorname{Teta1}(a-d)^{2}=.7438$} & \multicolumn{3}{|c|}{ rotal $(d-d)^{2}=17-344$} \\
\hline \multicolumn{2}{|c|}{$\begin{array}{l}\text { Art thmotileal } \\
\text { rean }\end{array}$} & -1.27 & Ardt & hesetton & -1.74 & \multicolumn{2}{|c|}{$\begin{array}{l}\text { ArI thmettoa } \\
\text { Wean }\end{array}$} & $=1.85$ \\
\hline \multicolumn{2}{|c|}{$\begin{array}{l}\text { Stundard } \\
\text { deviation }\end{array}$} & $= \pm 0.29$ & \multicolumn{2}{|c|}{$\begin{array}{l}\text { Standerd } \\
\text { derlation }\end{array}$} & $= \pm 0$ & \multicolumn{2}{|c|}{$\begin{array}{l}\text { Standand } \\
\text { derlation }\end{array}$} & $= \pm 0.43$ \\
\hline
\end{tabular}




\section{APPAODXX I}

STATISTTCAL DATA FOR 9:00 P*M.

\begin{tabular}{|c|c|c|c|c|c|c|c|c|}
\hline \multicolumn{3}{|c|}{ GLALR CBtTs } & \multicolumn{3}{|c|}{ CHEOMOSOKLT STACBS } & \multicolumn{3}{|c|}{ 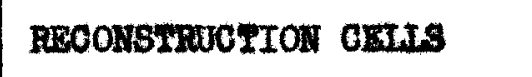 } \\
\hline d & $(d-d)$ & $(d-\bar{d})^{2}$ & d & $(d-d)$ & $(a-d)^{2}$ & d & $(a-d)$ & $(d-d)^{2}$ \\
\hline .04 & .84 & .7056 & .04 & .39 & $.152 n$ & .67 & 1.22 & 1.4884 \\
\hline 1.46 & .22 & .0484 & 1.17 & .06 & .0036 & 2.85 & .96 & .9226 \\
\hline 1.10 & .58 & .3364 & 1.07 & .16 & .0256 & 1.31 & .58 & .3364 \\
\hline 3.15 & 1.47 & 2.1609 & 1.55 & .32 & .2024 & 2.30 & .47 & .1682 \\
\hline 2.89 & 1.21 & 1.4641 & 1.37 &. $\mathrm{IH}_{4}$ & .0196 & 1.63 & .26 & .0676 \\
\hline .84 & .84 & .7056 & 1.31 & .08 & .0064 & 2.13 & .24 & .0576 \\
\hline 1.38 & .30 & .0900 & 1.01 & .22 & .04864 & 1.04 & .85 & .7225 \\
\hline .82 & .86 & .7396 & .98 & .25 & .0625 & 1.24 & .65 & .4225 \\
\hline 1.85 & .17 & .0289 & 1.01 & .22 & .0484 & 2.31 & .42 & .1764 \\
\hline 1.90 & .22 & .0484 & 1.40 & .17 & .0289 & 2.55 & .66 & .4356 \\
\hline \multicolumn{3}{|c|}{ Total $(a-\pi)^{2}=6.3279$} & \multicolumn{3}{|c|}{ Total $(d-d)^{2}=.4979$} & \multicolumn{3}{|c|}{ Totel $(d-d)^{2}=4.7967$} \\
\hline \multicolumn{2}{|c|}{$\begin{array}{l}\text { Art thwotical } \\
\text { Hean }\end{array}$} & -1.68 & \multicolumn{2}{|c|}{$\begin{array}{l}\text { Arithwetdeal } \\
\text { Hean }\end{array}$} & $=2.23$ & \multicolumn{2}{|c|}{$\begin{array}{l}\text { Art throticel } \\
\text { Lean }\end{array}$} & -1.89 \\
\hline \multicolumn{2}{|c|}{$\begin{array}{l}\text { Standard } \\
\text { deriation }\end{array}$} & $= \pm 0.26$ & \multicolumn{2}{|c|}{$\begin{array}{l}\text { Standard } \\
\text { deviation }\end{array}$} & $= \pm 0.07$ & \multicolumn{2}{|c|}{ of $\begin{array}{l}\text { Standard } \\
\text { deviation }\end{array}$} & $= \pm 0.23$ \\
\hline
\end{tabular}


APPADIX I

STATISTICAL DATA FOR 20,00 P.M.

\begin{tabular}{|c|c|c|c|c|c|c|c|c|}
\hline \multicolumn{3}{|c|}{ CLRAR Cruxs } & \multicolumn{3}{|c|}{ GHRONOSONA: STAGES } & \multicolumn{3}{|c|}{ RECONSTRUCTION OBIJS } \\
\hline$d$ & $(d-\pi)$ & $(d-2)^{2}$ & d & $(d-\pi)$ & $(d-\pi)^{2}$ & d & $(d-d)$ & $(d-\bar{d})^{2}$ \\
\hline .72 & .46 & .2116 & 2.05 & .39 & .1521 & 1.22 & .72 & .5184 \\
\hline .49 & .69 & .4761 & 1.9 & .54 & .2916 & 1.67 & .27 & .0729 \\
\hline .56 & .62 & .38444 & . & 1.95 & 3.8025 & .62 & 1.32 & 2.7424 \\
\hline 1.72 & .54 & .2916 & 3.02 & .58 & .3364 & 1.83 & .11 & $.022 x$ \\
\hline .68 & .50 & .2500 & 2.74 & .30 & .0900 & 2.43 & .49 & .2401 \\
\hline 2.84 & 1.66 & 2.7556 & 4.08 & 2.64 & 2.6896 & 5.65 & $3 . n$ & 13.7642 \\
\hline 1.02 & & .0256 & 2,61 & .27 & .0289 & .47 & 1.53 & 2.3409 \\
\hline \multicolumn{3}{|c|}{ Total $(d-d)^{2}=4.3949$} & \multicolumn{3}{|c|}{ Total $(d-d)^{2}=7.3917$} & \multicolumn{3}{|c|}{ motal $(d-\Phi)^{2}=18.6909$} \\
\hline \multicolumn{2}{|c|}{$\begin{array}{l}\text { Arlthrotsteal } \\
\text { Heen }\end{array}$} & -1.18 & \multicolumn{2}{|c|}{$\begin{array}{l}\text { Arithnotical } \\
\text { Hean }\end{array}$} & $=2.44$ & \multicolumn{2}{|c|}{$\begin{array}{l}\text { Arithnetical } \\
\text { Wean }\end{array}$} & $=1.94$ \\
\hline \multicolumn{2}{|c|}{$\begin{array}{l}\text { Standerd } \\
\text { deviation }\end{array}$} & $= \pm 0.3$ & $\begin{array}{l}\text { Star } \\
\text { der }\end{array}$ & ation & $= \pm 0$. & \multicolumn{2}{|c|}{$\begin{array}{l}\text { Standard } \\
\text { doviation }\end{array}$} & $= \pm 0.67$ \\
\hline
\end{tabular}


APPGIDIX I

BTATISHTCAL DATA FOR 11,00 P.M.

\begin{tabular}{|c|c|c|c|c|c|c|c|c|}
\hline \multicolumn{3}{|c|}{ Grand CBLS } & \multicolumn{3}{|c|}{ Chromosomat staoss } & \multicolumn{3}{|c|}{ RECONSTRUCTION OHIS } \\
\hline d & $(a-d)$ & $(d-a)^{2}$ & $d$ & $(d-d)$ & $(a-a)^{2}$ & d & $(a-\bar{a})$ & $(d-\pi)^{2}$ \\
\hline 4.66 & 1.47 & 2.1609 & 3.60 & 2,02 & 1,0201 & 3.86 & 1.37 & 1.8769 \\
\hline 3.28 & .09 & .0001 & 2.66 & .05 & .0025 & .69 & .80 & .6400 \\
\hline 3.42 & .23 & .0529 & 2.65 & .96 & .9216 & .87 & .62 & .3844 \\
\hline 3.46 & .27 & .0729 & 2.60 & +02 & .000 & $\mid 2.38$ & .89 & .7921 \\
\hline 3.99 & .80 & .6400 & 3.59 & 98 & .9604 & .84 & .65 & .4225 \\
\hline 3.52 & .33 & .1089 & 2.04 & .57 & .3249 & 1.02 & .47 & 1.0404 \\
\hline 2.57 & .67 & 4489 & 3.15 & .54 & .2916 & .89 & .60 & .3600 \\
\hline 4.02 & .83 & .6889 & 4.58 & 1.97 & 3.8809 & 4.18 & 2.69 & 7.2361 \\
\hline .77 & 2.42 & 5.8564 & 3.07 & 2.54 & 2.3716 & .38 & 1.11 & 1.2321 \\
\hline \multicolumn{3}{|c|}{ Total $(a-d)^{2}-13.8279$} & \multicolumn{3}{|c|}{$9 \operatorname{Total}(d-d)^{2}=9.7737$} & \multicolumn{3}{|c|}{ Total $(d-d)^{2}-13.9845$} \\
\hline \multicolumn{2}{|c|}{$\begin{array}{l}\text { Arl thmet1eal } \\
\text { Wean }\end{array}$} & $=3.19$ & \multicolumn{2}{|c|}{$\begin{array}{l}\text { Arithuetieal } \\
\text { Hean }\end{array}$} & -2.61 & \multicolumn{2}{|c|}{$\begin{array}{l}\text { Arl thrietical } \\
\text { Mean }\end{array}$} & -1.49 \\
\hline \multicolumn{2}{|c|}{$\begin{array}{l}\text { Standard } \\
\text { deriation }\end{array}$} & $= \pm 0.4$ & \multicolumn{2}{|c|}{$\begin{array}{l}\text { Standard } \\
\text { derlation }\end{array}$} & $= \pm 0.37$ & \multicolumn{2}{|c|}{$\begin{array}{l}\text { Standard } \\
\text { deviation }\end{array}$} & $= \pm 0.4$ \\
\hline
\end{tabular}




\section{APPEDDX I}

STATISTIOAI DATA FOR 12,00 MAdnight

\begin{tabular}{|c|c|c|c|c|c|c|c|c|}
\hline \multicolumn{3}{|c|}{ GIEAR CETIS } & \multicolumn{3}{|c|}{ CHROMOBOHAT STAGES } & \multicolumn{3}{|c|}{ PRCONSTRUCETON GRIS } \\
\hline a & $(d-a)$ & $\left(a-a^{2}\right)$ & $d$ & $(a-a)$ & $(a-d)^{2}$ & d & $(a-d)$ & $(d-a)^{2}$ \\
\hline 7.58 & 3.09 & 9.5401 & 5.06 & .99 & .9801 & 1.37 & .37 & .0289 \\
\hline 3.68 & .82 & .6561 & 7.22 & 2.17 & 1.3689 & 1.20 & . 34 & .2156 \\
\hline 3.38 & 1.11 & 1.232 & 7.91 & 2.86 & 3.4596 & 2.00 & .46 & .2116 \\
\hline 5.07 & .58 & $\cdot 3364$ & 6.12 & .07 & .0049 & 2.24 & .30 & .0900 \\
\hline 4.61 & .12 & .0244 & 5.22 & .83 & .6889 & 1.30 & .24 & .0576 \\
\hline 5.44 & .95 & .9025 & 7.15 & 1.10 & 1.2100 & 2.70 & 1.16 & 1.3456 \\
\hline 3.81 & .68 & .4624 & 5.02 & 1.04 & 2.0816 & .76 & .78 & .6084 \\
\hline 3.85 & .64 & .4096 & 5.20 & .85 & .7225 & 2.50 & .96 & .9216 \\
\hline 1.88 & 2.61 & 6.8121 & 6.14 & .09 & .0081 & .24 & 1.40 & 1.9600 \\
\hline 3.07 & 1.42 & 2.0264 & 5.52 & .53 & .2809 & 1.38 & .16 & .0256 \\
\hline \multicolumn{3}{|c|}{$\operatorname{Total}(d-d)^{2}=22.3901$} & \multicolumn{3}{|c|}{1 Total $(d-d)^{2}=9.8055$} & \multicolumn{2}{|c|}{ Total $(\mathrm{d}-\mathrm{d})^{2}$} & )$^{2}=5.3649$ \\
\hline \multicolumn{2}{|c|}{ Arithmetical } & -4.48 & \multicolumn{2}{|c|}{$\begin{array}{l}\text { Arithmotieal } \\
\text { Sean }\end{array}$} & -6.05 & \multicolumn{2}{|c|}{ Ari thmetical } & -1.54 \\
\hline \multicolumn{2}{|c|}{$\begin{array}{l}\text { Standard } \\
\text { derlation }\end{array}$} & $= \pm 0.49$ & \multicolumn{2}{|c|}{$\begin{array}{l}\text { Standard } \\
\text { deviation }\end{array}$} & \pm 0 & \multicolumn{2}{|c|}{$\begin{array}{l}\text { Standard } \\
\text { deviation }\end{array}$} & $= \pm 0.49$ \\
\hline
\end{tabular}




\section{APPENDIX I}

STATISTICAL DATA FOR I,00 A.M.

\begin{tabular}{|c|c|c|c|c|c|c|c|c|}
\hline \multicolumn{3}{|c|}{ CLEAR CKLIS } & \multicolumn{3}{|c|}{ CHROMOSOMAI STAGES } & \multicolumn{3}{|c|}{ ReCONSTRDCTION GEHS } \\
\hline d & $(d-\bar{d})$ & $(d-d)^{2}$ & d & $(d-\bar{d})$ & $(d-\bar{d})^{2}$ & d & $(d-\bar{d})$ & $(d-\bar{d})^{2}$ \\
\hline 4.40 & .81 & .6561 & $\mid 4.60$ & .26 & .0676 & 4.64 & 1.73 & 2.9929 \\
\hline 3.55 & .04 & .0016 & 7.35 & 2.49 & 6.2001 & 2.38 & .43 & .1849 \\
\hline 1.77 & 1.82 & 3.3124 & 3.22 & 1.64 & 2.6896 & 1.79 & 1.12 & 1.2544 \\
\hline 3.44 & .25 & .0225 & 5.55 & .69 & .4761 & 2.78 & .13 & .0169 \\
\hline 2.10 & 1.49 & 2.2201 & 4.62 & .24 & .0576 & 1.57 & 1.34 & 1.7956 \\
\hline 4.18 & .59 & .3481 & 4.33 & .53 & .2809 & 1.93 & .98 & .9604 \\
\hline 1.77 & 1.82 & 3.3224 & 3.69 & 1.17 & 1.3689 & 2.59 & 2.32 & 1.7424 \\
\hline 2.85 & .74 & .5476 & 4.10 & .76 & .5776 & 1.60 & 1.31 & 1.7160 \\
\hline 4.31 & .72 & .5184 & 6.22 & 2.35 & 5.5225 & 3.15 & .24 & .0576 \\
\hline 5.18 & 1.59 & 2.5281 & $\mid 5.89$ & 1.03 & 1.0609 & 5.92 & 3.01 & 9.0601 \\
\hline .59 & 3.00 & 9.0000 & 3.08 & 1.78 & 3.1684 & .83 & 2.08 & 4.3264 \\
\hline 8.46 & 4.84 & 23.4256 & 4.91 & .05 & .0025 & 4.92 & 2.00 & 4.0000 \\
\hline 2.14 & 1.45 & 2.1025 & 6.28 & 1.42 & 2.0264 & .94 & 1.97 & 3.8809 \\
\hline \multicolumn{3}{|c|}{ Totel $(d-d)^{2}=47.9954$} & \multicolumn{4}{|c|}{ Total $(d-d)^{2}=23.4891$} & Total (c & d) ${ }^{2}=31.9886$ \\
\hline \multicolumn{2}{|c|}{$\begin{array}{l}\text { Arithmetical } \\
\text { Lean }\end{array}$} & -3.59 & \multicolumn{2}{|c|}{$\begin{array}{l}\text { Ardthretical } \\
\text { Mean }\end{array}$} & $=4.86$ & & $\begin{array}{l}\text { Arlthmetical } \\
\text { Wean }\end{array}$ & a1 $=2.91$ \\
\hline \multicolumn{2}{|c|}{$\begin{array}{l}\text { Standard } \\
\text { doviation }\end{array}$} & $= \pm 0.5$ & \multicolumn{2}{|c|}{$\begin{array}{l}\text { Standard } \\
\text { deviation }\end{array}$} & $= \pm 0.3$ & & $\begin{array}{l}\text { Standard } \\
\text { deriation }\end{array}$ & $= \pm 0.45$ \\
\hline
\end{tabular}


APPEDIX I

SutrstrCat DATA FOR 2,00 A.H.

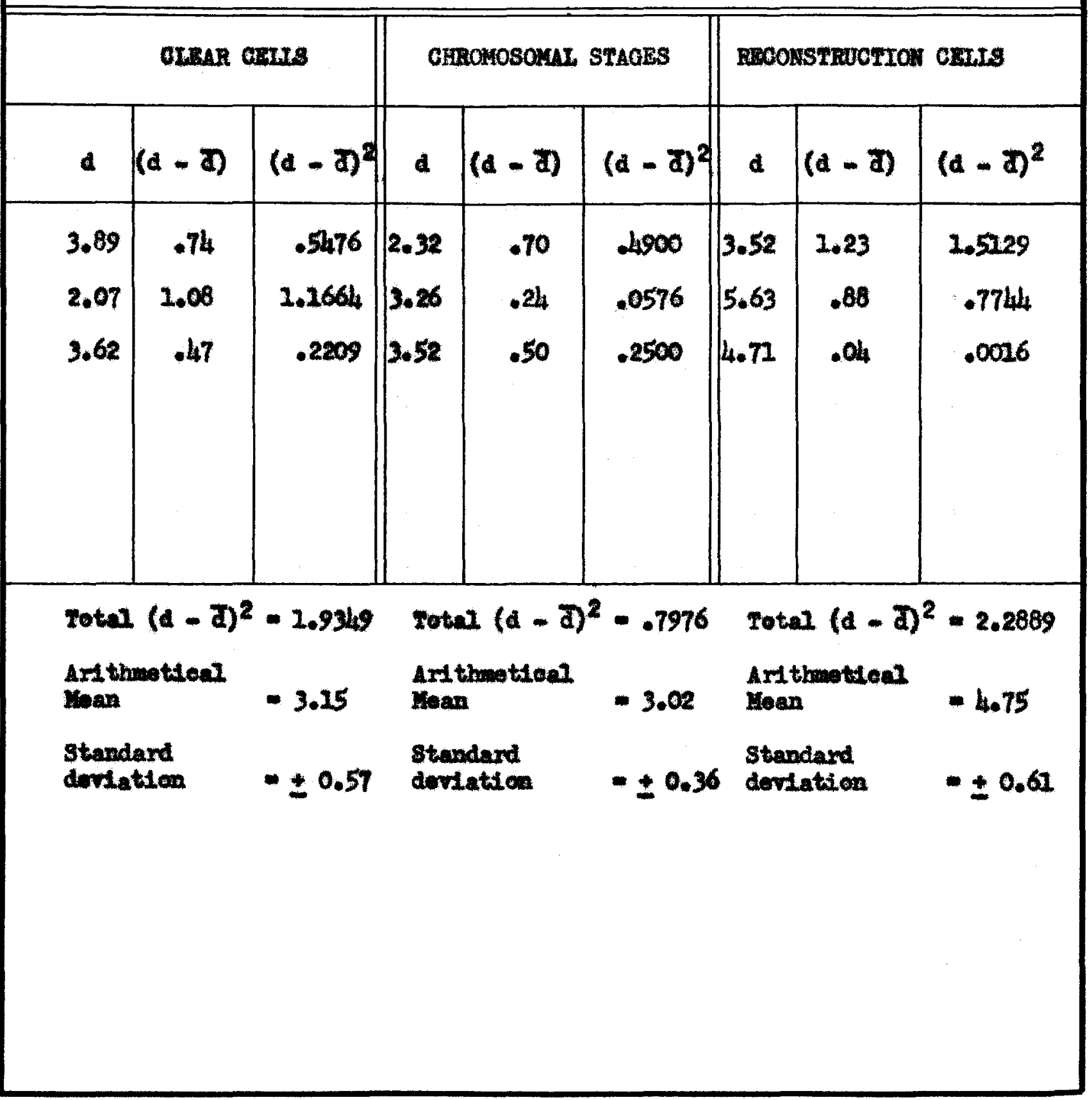


APPBDDIX 1

SWATISTran DATA FOR 3,00 A.K.

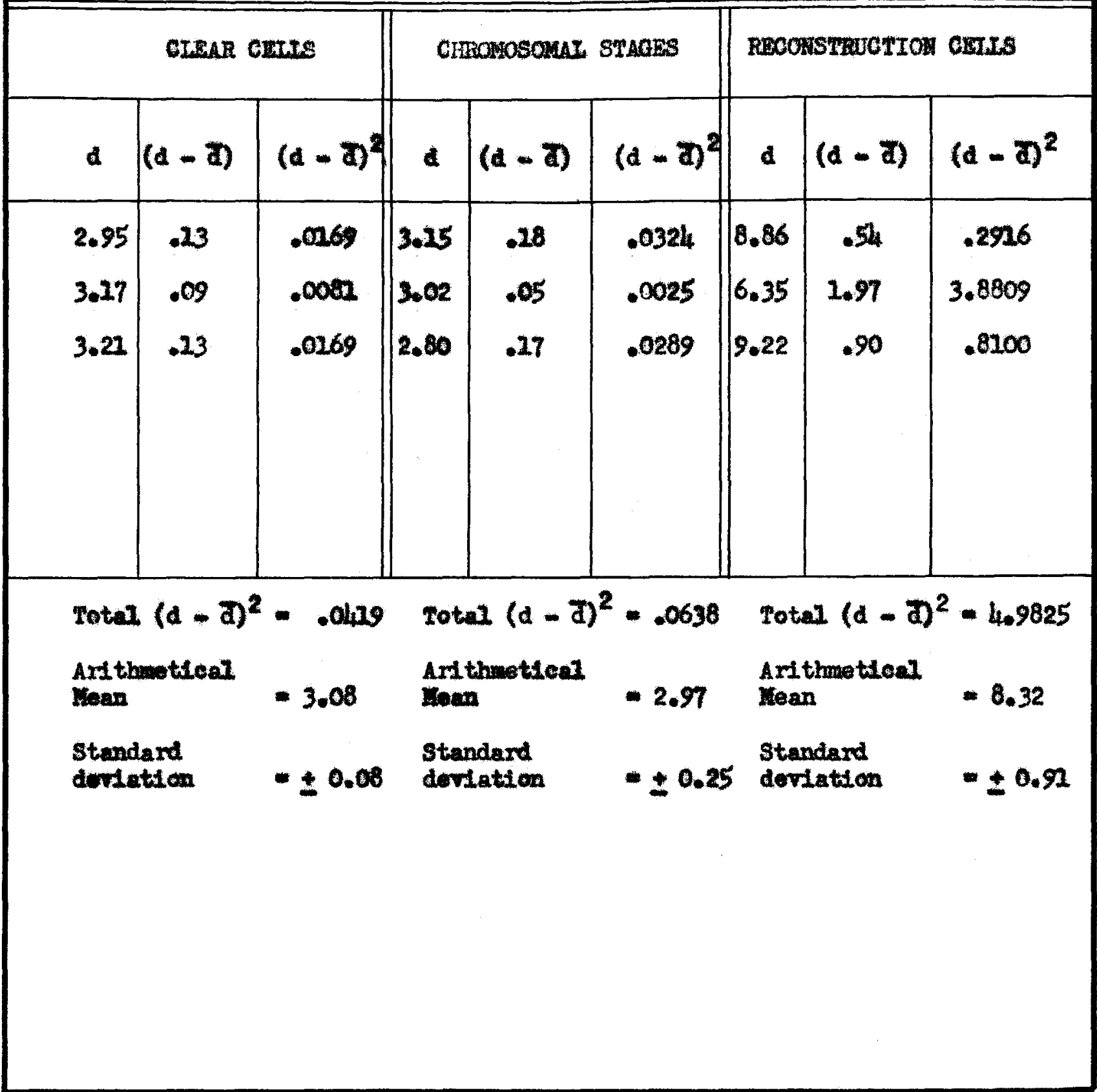


APPEMDIX I

STATIBTIOAI DATA FOR 4.00 A.K.

\begin{tabular}{|c|c|c|c|c|c|c|c|c|}
\hline \multicolumn{3}{|c|}{ CLBAR CRIS } & \multicolumn{3}{|c|}{ CHEOMOSOMAI SHACES } & \multicolumn{3}{|c|}{ PECONSTRUCTIOA CELIS } \\
\hline d & $(d-d)$ & $(d-d)^{2}$ & d & $(a-a)$ & $(d-a)^{2}$ & d & $(d-\bar{d})$ & $(d-\bar{d})^{2}$ \\
\hline 1.86 & .51 & .2602 & 1.83 & .22 & .0484 & 3.55 & .53 & .2809 \\
\hline 3.01 & 244 & .1936 & 1,9 & .06 & .0036 & 2.26 & 1.92 & 3.6864 \\
\hline .92 & 2.46 & 2.1316 & 1.36 & .69 & .4761 & 3.98 & .20 & .0100 \\
\hline 3.42 & 1.05 & 1.1025 & 2.20 & .25 & .0225 & 6.24 & 2.06 & 4.2436 \\
\hline 1.85 & .52 & .2704 & 2.06 &. $\mathbf{0}$ & $.000 \mathbf{m}$ & 4.32 & .14 & .0196 \\
\hline 2.26 & .11 & $.02 a$ & 3.75 & 1.70 & 2.8900 & 2.00 & 2.18 & 4.7524 \\
\hline 1.54 & .83 & .6889 & 1.89 & .16 & .0256 & $4 \cdot 2$ & .03 & .0009 \\
\hline 1.47 & .90 & .8100 & 2.65 & .60 & .3600 & 6.14 & 1.86 & 3.4596 \\
\hline \multicolumn{3}{|c|}{$\operatorname{Total}(d-d)^{2}=5.4692$} & \multicolumn{3}{|c|}{ Totel $(d-\bar{d})^{2}=3.8263$} & \multicolumn{3}{|c|}{ Total $(\mathrm{a}-\mathrm{d})^{2}=16.4834$} \\
\hline \multicolumn{2}{|c|}{$\begin{array}{l}\text { Arlthwettoal } \\
\text { lean }\end{array}$} & $=2.37$ & \multicolumn{2}{|c|}{$\begin{array}{l}\text { Ard thmotical } \\
\text { Iean }\end{array}$} & $=2.05$ & \multicolumn{2}{|c|}{$\begin{array}{l}\text { Aritmotica } \\
\text { Yean }\end{array}$} & $=4.28$ \\
\hline \multicolumn{2}{|c|}{$\begin{array}{l}\text { Standard } \\
\text { derriation }\end{array}$} & $= \pm 0.31$ & \multicolumn{2}{|c|}{$\begin{array}{l}\text { Standard } \\
\text { deviation }\end{array}$} & $= \pm 0.26$ & \multicolumn{2}{|c|}{$\begin{array}{l}\text { Standand } \\
\text { deviation }\end{array}$} & $= \pm 0.17$ \\
\hline
\end{tabular}




\section{APFRDIX I}

SHFTETIEA BATA TOR 5,00 A.

\begin{tabular}{|c|c|c|c|c|c|c|c|c|}
\hline \multicolumn{3}{|c|}{ OLXIR CDLLS } & \multicolumn{3}{|c|}{ CHromosonut STAOES } & \multicolumn{3}{|c|}{ 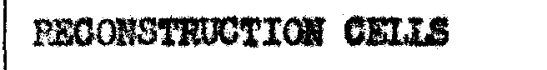 } \\
\hline a & $(d-\pi)$ & $(d-a)^{2}$ & a & $(a-d)$ & $(a-d)^{2}$ & $\mathbf{a}$ & $(a-d)$ & $(a-a)^{2}$ \\
\hline 2.09 & .22 & . Aly 84 & 1.12 & .88 & .7744 & 2.09 & 2,03 & 4.2209 \\
\hline 3.05 & 2.28 & 2.3924 & 2.39 & $-x$ & .2521 & 4.35 & .77 & .5929 \\
\hline 1.53 & .34 & .2156 & 1.63 & .37 & .1369 & 3.87 & .25 & .0625 \\
\hline 1.69 & .28 & .0324 & 1.79 & $\boldsymbol{n}$ & .0412 & 4.47 & .35 & .1225 \\
\hline 1.26 & .7 & .5042 & 2.60 & .60 & .3600 & 3.84 & .28 & .0784 \\
\hline 2.58 & $n$ & .5042 & 3.32 & 2.32 & 1.7424 & 4.51 & .39 & .1521 \\
\hline \multicolumn{3}{|c|}{ Total $(d-d)^{2}=2.5970$} & \multicolumn{3}{|c|}{ Total $(\mathrm{d}-\mathrm{d})^{2}=3.2099$} & \multicolumn{3}{|c|}{ Total $(d-J)^{2}=5.1293$} \\
\hline \multicolumn{2}{|c|}{$\begin{array}{l}\text { Axt the theal } \\
\text { Wean }\end{array}$} & -1.67 & \multicolumn{2}{|c|}{$\begin{array}{l}\text { Art thetieal } \\
\text { Nean }\end{array}$} & -2.00 & \multicolumn{2}{|c|}{$\begin{array}{l}\text { Ars thation } \\
\text { Man }\end{array}$} & -4.12 \\
\hline \multicolumn{2}{|c|}{$\begin{array}{l}\text { Stendard } \\
\text { devitation }\end{array}$} & $= \pm 0.2$ & \multicolumn{2}{|c|}{$\begin{array}{l}\text { Standurd } \\
\text { deviation }\end{array}$} & $= \pm 0.33$ & \multicolumn{2}{|c|}{$\begin{array}{l}\text { Standard } \\
\text { deviation }\end{array}$} & $=0.41$ \\
\hline
\end{tabular}




\section{APPROVAL SHEMT}

The Anertation ankitted by Lanrense B. Sohoving ha been read and epprowed by Iive members of the faculty of the Gradute sohool.

The Alnal coples have been exmined by the direoter of the dissertation and the signature which appears belem verifles the fact that any necessary changes have been inoorporated, and that the dissertation is nos given Inal approval with reference to sontent, fown, and mochenteal sceuracy.

The dissertation is therefore accepted in partial fulflinent of the requixments for the Degree of Dooter of Philesophy.
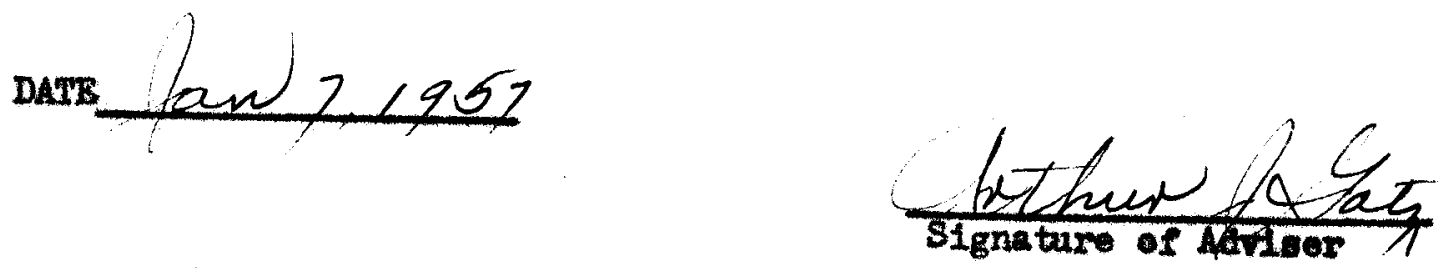